http://dx.doi.org/10.12775/RT.2019.002

Agnieszka Zielińska*

\title{
Przemiany struktury ludności Torunia i powiatu toruńskiego od połowy XIX wieku do drugiej wojny światowej
}

\author{
Changes in the structure of the population of Torun \\ and the Torun county from the mid- $19^{\text {th }}$ century to World War II \\ Veränderungen in der Bevölkerungsstruktur Thorns \\ und des Kreises Thorn von der Mitte des 19. Jahrhunderts \\ bis zum 2. Weltkrieg
}

\begin{abstract}
Streszczenie. Artykuł omawia zagadnienie przemian struktur ludności Torunia i powiatu toruńskiego od drugiej połowy XIX w. do okresu międzywojennego włącznie, zawiera także analizę materiału statystycznego pozyskanego z różnych typów źródeł. Dla drugiej połowy XIX w. do 1914 r. wykorzystano zestawienia statystyczne dla poszczególnych powiatów Prus Zachodnich za lata $1871,1885,1895,1905$ i 1910 . Wykorzystane również zostały informacje ze statystyk pruskich z XIX i początku XX w. Dla lat międzywojennych niezwykle pomocne były spisy ludności z 1921 i 1931 r. Omówiono sytuację ludnościową, wyznaniową, narodowościową i społeczno-gospodarczą w tym

${ }^{*}$ Historyk, dr hab. nauk humanistycznych, prof. UMK, pracownik Instytutu Historii i Archiwistyki UMK w Toruniu. Zainteresowania badawcze koncentruje wokół historii gospodarczej i społecznej XIX i XX wieku, a także demografii historycznej. Jest autorką 2 monografii, licznych artykułów naukowych oraz 2 podręczników szkolnych (współautorka). ORCID: 0000-0003-1016-225X
\end{abstract}


okresie na terenie Torunia i powiatu. Toruń był wówczas ważnym ośrodkiem przemysłowym, ale był też twierdzą i posiadał garnizon, co miało duży wpływ na rozwój miasta, jak i jego charakter już od czasów pruskich. Gminy wiejskie i obszary dworskie były terenami głównie rolniczymi, zróżnicowanymi pod względem wyznaniowym i narodowościowym. $Z$ krótkiego przeglądu informacji statystyczno-demograficznych wyłania się obraz ogromnych zmian w strukturze wyznaniowej i narodowościowej ludności, gdzie cezurą była I wojna światowa i odzyskanie przez Polskę niepodległości. Było to wynikiem procesu repolonizacji, który dokonywał się na terenie całego powiatu w latach dwudziestych XX w. Zwiększenie liczby ludności polskiej i katolickiej oraz wyraźny spadek liczby ludności niemieckiej i ewangelickiej (choć wyznania i narodowości nie można wprost utożsamiać) odzwierciedlały zmiany polityczne i tworzenie państwa polskiego na nowo po ponad stu latach.

\begin{abstract}
The article discusses the issue of changes in the structure of the population of Torun and the Torun county from the second half of the $19^{\text {th }}$ century to the interwar period. The article contains an analysis of statistical material obtained from various types of sources. For the period of the second half of the $19^{\text {th }}$ century to 1914 , statistical summaries were used for individual counties of West Prussia for the years 1871, 1885, 1895, 1905 and 1910. Information from Prussian statistics for the period of the $19^{\text {th }}$ and early $20^{\text {th }}$ centuries was also used. For the interwar period the censuses of 1921 and 1931 were extremely helpful. The population, denomination, nationality and socio-economic situation in this period in Torun and the county were discussed here. Throughout this period Toruń was not only an important industrial centre, but it was also a fortress and it had a garrison, which had affected the development of the city and its character since the Prussian period. Rural communes and court territories were mainly agricultural areas, diversified in terms of religious and national structure. From the short review of statistical and demographic information, there emerges a picture of huge changes in the denominational and national structure of the population, where the key chronological boundaries were World War I and the time when Poland regained independence. It was the result of the repolonization process that took place throughout the county in the 1920s. The increase in the number of Polish and Catholic inhabitants, along with a clear decrease in the number of the German and Evangelical populations (although denominations and nationalities cannot be directly identified) reflected political changes and the creation of the Polish state again after more than a hundred years.
\end{abstract}


Zusammenfassung. Der Artikel behandelt die Veränderungen in der Bevölkerungsstruktur Thorns und des Landkreises Thorn von der 2. Hälfte des 19. Jahrhunderts bis einschließlich zur Zwischenkriegszeit. Er enthält eine Analyse von statistischem Material, das aus verschiedenen Arten von Quellen gewonnen wurde. Für den Zeitraum von der 2. Hälfte des 19. Jahrhunderts bis zum Jahr 1914 wurden statistische Zusammenstellungen für einzelne Landkreise Westpreußens aus den Jahren 1871, 1885, 1895, 1905 und 1910 ausgewertet. Ebenfalls ausgewertet wurden Informationen aus preußischen Statistiken für den Zeitraum des 19. und den Beginn des 20. Jahrhunderts. Für die Zwischenkriegszeit waren die Bevölkerungsregister von 1921 und 1931 sehr hilfreich. Darin geht es um die Situation der Bevölkerung, der Konfessionen, der Nationalitäten und der sozialen und wirtschaftlichen Verhältnisse in diesem Zeitraum auf dem Gebiet von Thorn und des Landkreises. Thorn war während dieses gesamten Zeitraums ein wichtiges Industriezentrum, aber es war auch eine Festung und besaß eine Garnison, was schon seit der preußischen Zeit großen Einfluss auf die Entwicklung der Stadt und ihren Charakter hatte. Die Landgemeinden und die Gutsbezirke waren hauptsächlich landwirtschaftliches Terrain, das in seiner konfessionellen und nationalen Struktur differenziert war. Eine kurze Betrachtung der statistisch-demografischen Informationen ergibt ein Bild von enormen Veränderungen in der konfessionellen und nationalen Struktur der Bevölkerung, wobei der 1. Weltkrieg und die Wiedererlangung der Unabhängigkeit durch Polen eine Schlüsselgrenze bilden. Dies war eine Folge des Prozesses der Repolonisierung, der in den zwanziger Jahren des 20. Jahrhunderts auf dem Gebiet des gesamten Landkreises stattfand. Die zahlenmäßige Vergrößerung der katholischen Bevölkerung und der deutliche Abfall der deutschen und evangelischen Bevölkerung (auch wenn Bekenntnis und Nationalität nicht einfach identifiziert werden dürfen) spiegelten die politischen Veränderungen und die Neuschöpfung des polnischen Staats nach über 100 Jahren wider.

Słowa kluczowe: Toruń, wyznanie, narodowość, powiat toruński, Prusy Zachodnie, I wojna światowa, zabory

Keywords: Torun, religion, nationality, the county of Torun, West Prussia, World War I, partitions

Schlüsselwörter: Thorn, Konfession, Nationalität, Landkreis Thorn, Westpreußen, 1. Weltkrieg, Teilungen 
Toruń, jak również omawiany tutaj obszar ówczesnego powiatu toruńskiego, wchodził w skład zaboru pruskiego przez ponad 100 lat. Wpływało to nie tylko na sytuację polityczną i administracyjną tego terenu, ale także na gospodarkę oraz strukturę zawodową, wyznaniową i narodowościową. Włączenie badanego obszaru do państwa polskiego wpłynęło na wiele zmian w społeczeństwie.

Celem artykułu jest przedstawienie zmian narodowościowych i wyznaniowych, które dokonały się $\mathrm{w}$ społeczeństwie Torunia $\mathrm{i}$ powiatu toruńskiego, zarówno w miastach, jak i na terenach wiejskich; ukazanie, jak ważne były utworzenie II Rzeczypospolitej i nowe warunki polityczne; określenie, w jaki sposób wpłynęły one na strukturę narodowościową i wyznaniową. Celem jest także omówienie rozwoju demograficznego i gospodarczego poszczególnych miast, gmin wiejskich i obszarów dworskich. Szczególnie dużo uwagi poświęcono tutaj Toruniowi. Starano się uzyskać odpowiedź na pytanie: jaka była pozycja tego miasta jeszcze w okresie pruskim, a następnie w okresie międzywojennym, i co na nią wpływało.

Artykuł zawiera analizę materiału statystycznego z różnych typów źródeł. Dla drugiej połowy XIX w. do 1914 r. wykorzystano zestawienia statystyczne dotyczące poszczególnych powiatów Prus Zachodnich za lata $1871,1885,1895,1905$ i $1910^{1}$. Wykorzystane także zostały informacje z publikacji Leszka Belzyta, który posiłkował się statysty-

\footnotetext{
${ }^{1}$ Die Gemeinden und Gutsbezirke des Preussischen Staates und ihre Bevölkerung. 1, Die Gemeinden und Gutsbezirke der Provinz Preussen und ihre Bevölkerung: nach den Urmaterialien der allgemeinen Volkszählung vom 1. December 1871, bearb. und zusammengestellt, Königlichen statistischen Bureau, Berlin 1874; Gemeindelexikon für die Provinz Westpreussen: auf Grund der Materialien der Volkszählung vom 1. Dezember 1885 und anderer amtlicher Quellen, bearb. vom Königlichen statistischen Bureau, Berlin 1887; Gemeindelexikon für die Provinz Westpreussen: auf Grund der Materialien der Volkszählung vom 2. Dezember 1895 und anderer amtlicher Quellen, bearb. vom Königlichen statistischen Bureau, Berlin 1898; Gemeindelexikon für die Provinz Westpreussen: auf Grund der Materialien der Volkszählung vom 1. Dezember 1905 und anderer amtlicher Quellen, bearb. vom Königlich Preussischen Statistischen Landesamte, Berlin: Verlag des Königlichen Statistischen Landesamts, 1908; Gemein delexikon für die Regierungsbezirke Allenstein, Danzig, Marienwerder, Posen, Bromberg und Oppeln: auf Grund der Ergebnisse der Volkszählung vom 1. Dezember 1910 und anderer amtlicher Quellen, H. 3, Regierungsbezirk Marienwerder, bearb. von Königlich Preußischen Statistischen Landesamte, Berlin 1912.
} 
kami pruskimi z XIX i początku XX w. ${ }^{2}$ Dla okresu międzywojennego niezwykle pomocne były spisy ludności z 1921 i 1931 r. $^{3}$ Źródła pruskie mają oczywiście zupełnie inny charakter niż międzywojenne spisy ludności. Mimo wszystko jednak wykorzystano tutaj jedne i drugie, aby pokazać zasadnicze zmiany w strukturach ludności, które nastąpiły $\mathrm{w}$ Toruniu i powiecie toruńskim $\mathrm{w}$ omawianym czasie.

Powiat toruński powstał w $1818 \mathrm{r}$. w wyniku nowego podziału administracyjnego Prus Zachodnich. Rejencja kwidzyńska została podzielona na 13 powiatów. Stan taki utrzymał się przez cały okres pruski, choć w 1887 r. część powiatu toruńskiego została włączona do nowo utworzonego powiatu wąbrzeskiego, a w 1900 r. utworzono powiat miejski Torun ${ }^{4}$. W okresie międzywojennym wchodził w skład województwa pomorskiego. Sam Toruń, podobnie zresztą jak Grudziądz, był powiatem miejskim, a także stolicą województwa ${ }^{5}$.

Toruń znalazł się pod okupacją pruską w 1793 r., po drugim rozbiorze Polski (tabela 1). Liczba ludności miasta na początku panowania pruskiego wynosiła poniżej 6 tysięcy osób, jednak na skutek napływu kadry urzędniczej, jak i rozwoju garnizonu (napływu żołnierzy, ale też członków rodzin wojskowych), a przez to ożywienia gospodarczego, liczba ludności zaczęła wzrastać nawet do 9 tysięcy osób cywilnych,

\footnotetext{
${ }^{2}$ L. Belzyt, Sprachlische Minderheiten im preussischen Staat 1815-1914. Die preussische Sprachenstatistik in Bearbeitung und Kommentar, Marburg 1998, s. 106

${ }^{3}$ Pierwszy powszechny spis Rzeczypospolitej Polskiej z 30.IX.1921 r. Województwo pomorskie. Mieszkania. Ludność. Stosunki zawodowe, Warszawa 1926; Skorowidz miejscowości Rzeczypospolitej Polskiej, t. XI, Województwo pomorskie, Warszawa 1926; Drugi powszechny spis ludności z dnia 9. XII.1931 roku. Mieszkania i gospodarstwa domowe. Ludność. Stosunki zawodowe. Województwo pomorskie, Warszawa 1938.

${ }^{4}$ S. Salmonowicz, Podziaty terytorialne $i$ ustrój polityczny ziem pomorskich w latach 1815-1850, [w:] Historia Pomorza, t. 3 (1815-1850), cz. 1: Gospodarka, społeczeństwo, ustrój, red. G. Labuda, Poznań 1993, s. 55-176; tenże, Administracja i prawo w prowincjach pomorskich, [w:] Historia Pomorza, t. 4 (1850-1918), cz. 1: Ustrój, gospodarka, społeczeństwo, red. S. Salmonowicz, Toruń 2000, s. 31-69.

${ }^{5}$ S. Salmonowicz, Podziaty terytorialne $i$ organizacja administracji $w$ województwie pomorskim (1920-1939), [w:] Historia Pomorza, t. 5 (1918-1939). Województwo pomorskie i Wolne Miasto Gdańsk, cz. 1: Ustrój, społeczeństwo i gospodarka, red. Sz. Wierzchosławski, P. Olstowski, Toruń 2015, s. 72-74, 77.
} 
Tabela 1

Liczba ludności na terenie powiatu toruńskiego w latach 1871-1931

\begin{tabular}{|c|c|c|c|c|c|}
\hline Lata & Toruń & Chełmża & Podgórz $\begin{array}{r}\text { Gminy } \\
\text { i obszary } \\
\text { dworskie }\end{array}$ & Razem \\
\hline 1871 & 16619 & 2982 & $\begin{array}{r}50839 \text { (Podgórz - 1108 } \\
\text { mieszkańców) }\end{array}$ & 70440 \\
\hline 1885 & 23906 & 4968 & $\begin{array}{r}48537 \text { (Podgórz - 1972 } \\
\text { mieszkańców) }\end{array}$ & 77411 \\
\hline 1895 & 27894 & 7579 & $\begin{array}{r}57221 \text { (Podgórz }-2945 \\
\text { mieszkańców) }\end{array}$ & 92694 \\
\hline 1905 & 43658 & 10007 & 3619 & 44904 & 102188 \\
\hline 1910 & 46227 & 10612 & 3638 & 44815 & 105292 \\
\hline 1921 & 39424 & 10648 & 3232 & 39893 & 93197 \\
\hline 1931 & 53993 & \multicolumn{2}{|c|}{16180} & 44023 & 114196 \\
\hline
\end{tabular}

Źródło: Die Gemeinden und Gutsbezirke, s. 434-443; Gemeindelexikon für die Provinz Westpreussen: auf Grund der Materialien der Volkszählung vom 1. Dezember 1885, s. 112-119; Gemeindelexikon für die Provinz Westpreussen: auf Grund der Materialien der Volkszählung vom 2. Dezember 1895, s. 108-117; Gemeindelexikon für die Provinz Westpreussen: auf Grund der Materialien der Volkszählung vom 1. Dezember 1905, s. 138-145; Gemeindelexikon für die Regierungsbezirke, s. 76-83; Skorowidz miejscowości Rzeczypospolitej Polskiej, s. 56-60; Drugi powszechny spis ludności, s. 35.

wliczając w to rodziny wojskowych ${ }^{6}$. Dobra koniunktura gospodarcza $\mathrm{w}$ Toruniu po kongresie wiedeńskim trwała do drugiej połowy lat dwudziestych XIX w. Związane to było z intensywnymi pracami fortyfikacyjnymi, odbudową po zniszczeniach wojennych oraz rozbudową infrastruktury garnizonu toruńskiego ${ }^{7}$. Rozbudowująca się twierdza,

${ }^{6}$ K. Mikulski, Poczatki zaboru pruskiego (1793-1806), [w:] Historia Torunia, red. M. Biskup, t. 3, cz. 1: W czasach zaboru pruskiego (1793-1920), Toruń 2003, s. 9, 15-30.

${ }^{7}$ K. Biskup, L. Narębski, Prusko-niemiecka twierdza Toruń (1815-1914), [w:] Historia Torunia, t. 3, cz. 1, s. 162-167. 
wzrastająca liczba stałego wojska wraz z przybywającymi do Torunia urzędnikami niemieckimi poważnie wpłynęły na charakter miasta. Stawało się ono coraz bardziej miastem garnizonowym i urzędniczym $^{8}$. Od 1816 r. liczba ludności wzrosła z 7 do 10 tysięcy w 1826 r. Stagnacja gospodarcza lat trzydziestych i czterdziestych oraz niepewna sytuacja ekonomiczna przyczyniły się do spadku liczby imigrantów, a także przyrostu naturalnego, co skutkowało zmniejszeniem liczby ludności do 8 tysięcy w 1832 r. ${ }^{9} \mathrm{~W}$ pierwszej połowie XIX w. Toruń był ośrodkiem rzemieślniczo-handlowym. Funkcjonowały tu nieliczne zakłady, głównie gorzelnie i browary. Największym zakładem była zlokalizowana na Bydgoskim Przedmieściu cegielnia miejska, choć zatrudniała ona tylko kilkunastu robotników. Liczba ludności zaczęła rosnąć ponownie dopiero w latach czterdziestych XIX w. i przekroczyła 9 tysięcy w $1841 \mathrm{r}^{10}$

W drugiej połowie XIX w. w Toruniu nastąpił szybszy niż dotychczas rozwój gospodarczy. Rozwijały się więc pomyślnie założone w 1842 r. odlewnia i zakład budowy maszyn E. Drewitza oraz założony w 1856 r. zakład firmy Born \& Schütze na Mokrem. Trzeba zaznaczyć, że te dwa przedsiębiorstwa utrzymały monopol w tej gałęzi przemysłu w mieście aż do okresu II Rzeczypospolitej. Bardzo duże znaczenie dla rozwoju tej branży miały zamówienia związane z rozbudową i przebudową twierdzy toruńskiej w drugiej połowie XIX w. Powstawały też tartaki parowe - w 1910 r. było ich w Toruniu już 11 oraz zakłady stolarki budowlanej, a impulsem do rozwoju przemysłu drzewnego było otwarcie w 1904 r. portu drzewnego. W przemyśle spożywczym dominowały zakłady piernikarskie, np. fabryka firmy

\footnotetext{
${ }^{8}$ K. Ciesielska, Ustrój i organizacja władz i kancelarii miasta Torunia $w$ latach 1793-1919, Warszawa 1972, s. 15.

${ }^{9}$ B. Wachowiak, Sytuacja gospodarcza Prus Zachodnich w świetle sprawozdania Prowincjonalnej Dyrekcji Podatkowej w Gdańsku za 1840 rok, Acta Universitatis Nicolai Copernici, Historia XXX - Nauki Humanistyczno-Społeczne, z. 322, Toruń 1997, s. 125-134. Zob. dokładne informacje na temat imigrantów przybywających do Torunia w pierwszej połowie XIX w.: A. Zielińska-Nowicka, $W$ poszukiwaniu lepszego jutra. Procesy migracyjne mieszkańców Torunia w I połowie XIX wieku, Toruń 2006.

${ }^{10}$ K. Wajda, Pod ponownym pruskim panowaniem (1815-1920), [w:] Toruń dawny i dzisiejszy, red. M. Biskup, Warszawa 1983, s. 341.
} 
Weese, fabryka firmy H. Thomas, działały też: młyn zbożowy Gersona, dwie mleczarnie, krochmalnia, dwa browary, gorzelnia i rektyfikacja spirytusu firmy Sułtan. W przemyśle chemicznym należy wymienić gazownię miejską zatrudniającą 84 robotników, fabrykę nawozów sztucznych, olejarnię firmy Längner \& Ilgner. Na przełomie XIX i XX w. w Toruniu rozwijał się również przemysł poligraficzny. Wspomnieć tu trzeba trzy drukarnie: zakład Buszczyńskich, zakład E. Dombrowskiego i drukarnię „Thorner Zeitung”. W branży odzieżowej dominowała wytwórnia obuwia firmy Kunze \& Kittel. Mimo istnienia tych przedsiębiorstw można jednak stwierdzić, że w Toruniu na początku XX w. nadal dominowały rzemiosło i mniejsze zakłady przemysłowe. $\mathrm{W}$ mieście funkcjonowało również ponad dwieście zakładów $\mathrm{z}$ branży gastronomicznej i hotelarskiej. Druga połowa XIX i początek XX w. w porównaniu z pierwszym pięćdziesięcioleciem XIX w. były czasem korzystnej koniunktury gospodarczej, co przyciągało rzesze robotników do miasta. Te przemiany Torunia w zakresie industrializacji były ważnym czynnikiem wpływającym na procesy demograficzne. Liczba ludności wzrosła do 46227 mieszkańców w 1910 r. ${ }^{11}$ Po I wojnie światowej spadła do 39424 mieszkańców w 1921 r., co było nie tylko skutkiem wojny, lecz także odpływu Niemców i Żydów, którzy w większości zdecydowali się optować na rzecz Niemiec. Już jednak w 1931 r. odnotowano 53993 mieszkańców miasta, co wiązało się z napływem Polaków i Żydów z innych dzielnic kraju, ale wynikało też z przyrostu naturalnego i procesów migracyjnych rozrastającego się miasta. W 1936 r. odnotowano tutaj 64,7 tysiąca mieszkańców, a w 1938 r. 75,9 tysiąca mieszkańców ${ }^{12}$.

W 1831 r. liczba ludności Chełmży wynosiła 1185 osób, w 1871 r. - 2982. Ważną datą dla Chełmży był rok 1882, zmienił on bardzo wie-

${ }^{11}$ J. Salm, Przemiany przestrzenne pruskiego Torunia (1815-1914), [w:] Historia Torunia, t. 3, cz. 1, s. 84-91; K. Wajda, Ludność Torunia (1815-1914), ibid., s. 99141; tenże, Życie gospodarcze miasta (1815-1914), ibid., s. 142-159. Zob. też: A. Zielińska, Przemiany struktur demograficznych $w$ Toruniu $w$ XIX i na początku XX wieku, Torun 2012.

${ }^{12}$ R. Sudziński, Spoleczeństwo międzywojennego Torunia, [w:] Historia Torunia, red. M. Biskup, t. 3, cz. 2: W czasach Polski Odrodzonej i okupacji niemieckiej (19201945), Torun 2006, s. 41-45. 
le w gospodarce tego miasta, jak i demografii. Uruchomiono wówczas w mieście cukrownię. Jej start był udany i już po zakończeniu pierwszej kampanii myślano o dalszej rozbudowie. Warunki ku temu były dobre: korzystne ceny cukru na rynku, tania siła robocza, dobra ziemia pszeniczno-buraczana gwarantująca wysokie plony. W roku 1885 wyniki kampanii były tak dobre, że cukrownia ta pod względem produkcji stała się największą $w$ granicach zaboru i państwa niemieckiego ${ }^{13}$. Uruchomienie cukrowni w 1882 r. otworzyło nowy okres w dziejach Chełmży. Nastąpiło przekształcanie się miasta z ośrodka rzemiosła i handlu w lokalny ośrodek przemysłowy. W 1904 r. doszło do wielkiego pożaru $\mathrm{w}$ zakładzie, co doprowadziło do przymusowej przebudowy i rozbudowy cukrowni, a w konsekwencji spowodowało, iż stała się ona jedną $\mathrm{z}$ największych $\mathrm{w}$ Europie $^{14}$. Ta nowa sytuacja wywarła znaczny wpływ na rozwój ludnościowy Chełmży i skład społecznozawodowy i narodowościowy jej mieszkańców. Liczba ludności bardzo szybko wzrosła do 10612 osób w 1910 r. Przybywali tu Niemcy związani z kierownictwem technicznym i administracją cukrowni, przedsiębiorcy, kupcy, rzemieślnicy. Równocześnie napływała wielka fala robotniczej ludności polskiej z okolic, dzięki czemu Chełmża nabrała charakteru miasta robotniczego. W 1894 r. zbudowano linię kolejową Bydgoszcz - Unisław - Kowalewo, w 1901 r. zaś linię Chełmża Mełno. W drugiej połowie XIX w. w Chełmży rozwijały się także inne zakłady. W 1875 r. powstała mleczarnia parowa, a w latach osiemdziesiątych zakład budowy maszyn Augusta Lorckego. W 1886 r. rozpoczęła działalność fabryczka papy braci Richert. Powstała tu też firma budowlana z tartakiem Georga Rotha. W 1907 r. w mieście obok cukrowni działały dwie cegielnie, trzy tartaki parowe, dwie fabryczki papy dachowej, dwa zakłady branży maszynowej, browar oraz mleczarnia. Aż po I wojnę światową cukrownia utrzymywała jednak wiodącą pozycję w przemyśle chełmżyńskim ${ }^{15}$. Liczba ludności Chełmży

\footnotetext{
${ }^{13}$ M. Bartko, W. Lau, 100 lat cukrowni Chetmża 1882-1982, Chełmża 1982, s. 2531; K. Wajda, Chetmża pod zaborem pruskim (do 1914 r.), [w:] Dzieje Chetmży, red. M. Wojciechowski, Chełmża 1994, s. 86, tabela 6, s. 106, tabela 18. s. 48.

${ }^{4}$ L. Belzyt, Dzieje Chetmży w okresie międzywojennym (1920-1939), Toruń 2001,

${ }^{15}$ K. Wajda, Chetmża pod zaborem pruskim (do 1914 r.), s. 75-144.
} 
tuż po zakończeniu wojny w 1919 r. wynosiła 11756 mieszkańców. W spisie z 1921 r. odnotowuje się tylko 10684 osoby, co zapewne jest częściowo wynikiem odpływu Niemców z miasta. Odnotowywano, iż do 1926 r. wyjechało z Chełmży około 2000 Niemców. W 1931 r. miasto zamieszkiwały 11443 osoby, a w 1938 r. już 12837 osób ${ }^{16}$.

Od 1818 r. Podgórz należał do nowo powołanego powiatu toruńskiego. W wyniku wprowadzenia w Prusach w 1832 r. nowej ordynacji dla miast i referendum przeprowadzonego w 1833 r. Podgórz został zaliczony do gmin wiejskich. Tym samym utracił otrzymane w $1611 \mathrm{r}$. prawa miejskie. Wprawdzie od 1845 r. funkcjonował on na podstawie statutu miejskiego, ale bez formalnego przywrócenia praw miejskich. Przerwa w funkcjonowaniu tego rozwiązania nastąpiła w latach 18741894, kiedy to zatwierdzony został nowy statut dla ,gminy” Podgórz, utrzymujący organizację władz na wzór miejski, ale nadal bez przywrócenia praw miejskich ${ }^{17}$. W związku z tym $\mathrm{w}$ materiałach statystycznych za lata 1905 i 1910 Podgórz wymieniany jest wśród miast.

Ludność Podgórza w XIX w. zajmowała się głównie hodowlą bydła, rolnictwem i rzemiosłem. Działały tam też gospody, wyszynki, młyn wodny. Brakowało tu jednak przemysłu. Pozytywne zmiany nastąpiły w drugiej połowie XIX w. po uruchomieniu połączeń kolejowych, powstaniu Dworca Głównego oraz rozbudowie i przebudowie toruńskich fortyfikacji, co pozwoliło wielu mieszkańcom Podgórza na znalezienie pracy na kolei lub w wojsku. Coraz chętniej na terenie Podgórza zamieszkiwali wojskowi, ale też uciekinierzy z zaboru rosyjskiego. Te zmiany pociągnęły za sobą rozwój gospodarczy Podgórza. Przed I wojną światową działały tu już browar R. Thomsa, tartaki, rozwijały się handel i rzemiosło. Funkcjonowały dwa młyny, fabryczka cygar, drogerie, wyszynki i gospody. Mieszkali tu nauczyciele, urzędnicy miejscy, kolejowi i wojskowi. W 1907 r. zbudowano nowy ratusz. Liczba ludności wzrosła w 1910 r. do 3638 osób. Po I wojnie światowej w pierwszym spisie ludności z 1921 r. Podgórz pojawia się

\footnotetext{
${ }^{16}$ Z. Karpus, Chetmża w okresie międzywojennym, [w:] Dzieje Chetmży, s. 172, tabela 1 .

${ }^{17}$ K. Ciesielska, T. Zakrzewski, 450 lat toruńskiego Podgórza 1555-2005, Toruń 2005, s. 63 .
} 
jako miasto, choć zgodnie z dokumentami dopiero w 1923 r. otrzymał on nowy statut, a w 1924 r. Rada Ministrów nadała Podgórzowi prawa miejskie. Taka sytuacja utrzymała się do 1938 r., kiedy to Podgórz został włączony do Torunia ${ }^{18}$. W $1921 \mathrm{r}$. liczył 3232 mieszkańców, w 1927 r. - 4760, a w 1932 r. - 4863, w tym 4728 Polaków. W chwili przyłączenia do Torunia w Podgórzu mieszkało jeszcze około 2 tysięcy osób więcej ${ }^{19}$.

Liczebność gmin wiejskich i obszarów dworskich powiatu toruńskiego zmieniała się w badanym okresie. Wpływ na to miał nie tylko ruch naturalny ludności czy też procesy migracyjne, ale także zasygnalizowane już zmiany administracyjne, jak również liczba mieszkańców Podgórza, który przez pewien czas wliczany był do gmin wiejskich. Liczebność mieszkańców wahała się więc między 40 a 57 tysiącami.

Tabela 2

Ludność cywilna i wojskowa Torunia w latach 1885-1910

\begin{tabular}{|c|c|c|c|}
\hline Lata & $\begin{array}{c}\text { Ludność cywilna } \\
\text { łącznie }\end{array}$ & Wojsko & $\begin{array}{c}\text { Ludność Torunia } \\
\text { łącznie }\end{array}$ \\
\hline 1885 & 23906 & 4401 & 28307 \\
\hline 1895 & 27894 & 5366 & 33260 \\
\hline 1905 & 43658 & 5638 & 49296 \\
\hline 1910 & 46227 & 5702 & 51929 \\
\hline
\end{tabular}

Źródło: Gemeindelexikon für die Provinz Westpreussen: auf Grund der Materialien der Volkszählung vom 1. Dezember 1885, s. 112-113; Gemeindelexikon für die Provinz Westpreussen: auf Grund der Materialien der Volkszählung vom 2. Dezember 1895, s. 108-109; Gemeindelexikon für die Provinz Westpreussen: auf Grund der Materialien der Volkszählung vom 1. Dezember 1905, s. 138-139; Gemeindelexikon für die Regierungsbezirke, s. 76-77.

\footnotetext{
${ }^{18}$ Ibid., s. 71

${ }^{19}$ Ibid., s. 73
} 
Pisząc o strukturze demograficznej Torunia należy pamiętać, iż funkcjonujący w mieście garnizon wojskowy znacznie wpływał na demografię miasta, jak też na jego rozwój gospodarczy i obraz społeczeństwa (tabela 2). Toruń nabierał charakteru miasta garnizonowego, gdyż stacjonowali tutaj nie tylko skoszarowani żołnierze, ale także kadra oficerska i członkowie jej rodzin. W $1871 \mathrm{r}$. było w Toruniu 1757 wojskowych, jednak przebudowa i rozbudowa twierdzy toruńskiej od końca lat siedemdziesiątych do początku lat dziewięćdziesiątych wpłynęła na szybkie powiększenie stanu liczebnego garnizonu toruńskiego. Na przełomie XIX i XX w. wojskowi stanowili od 4401 do 5702 osób w granicach administracyjnych miasta, $\mathrm{z}$ tendencją wzrostową. Mieszkali oni jednak także w podmiejskich miejscowościach, między innymi Rudaku, gdzie znajdowały się koszary, jak też Podgórzu, Piaskach, Wrzosach, Bielawach ${ }^{20}$.

Toruń w XIX w. był miastem zamieszkanym w dużej części przez ewangelików (wykres 1). Jedynie w 1816 i 1818 r. katolicy stanowili powyżej $50 \%$ ogółu mieszkańców. Po ponownym przejęciu miasta przez Prusaków ewangelicy szybko stali się dominującą grupą wyznaniową. Taka sytuacja utrzymywała się w kolejnych latach. I choć liczby rzeczywiste katolików niejednokrotnie rosły, to odsetek malał, ponieważ wzrost liczby ewangelików był jeszcze większy. Napływ ludności ewangelickiej wiązał się z imigracją urzędników, funkcjonariuszy, nauczycieli pruskich, a także z przybywaniem robotników do prac budowlanych. Szczególnie w latach trzydziestych widać było wyraźny spadek liczby katolików w Toruniu - zarówno w liczbach rzeczywistych, jak i względnych (około 40\%), przy wzroście znaczenia ewangelików do 55,6\%. Taka sytuacja mogła oczywiście być po części rezultatem epidemii cholery, która nawiedziła Toruń w 1831 r. i spowodowała śmierć między innymi ludności katolickiej uznawanej za uboższą. Spadek ten był jednak głównie konsekwencją odpływu ludności niewykwalifikowanej z powodu zakończenia prac budowlanych w Toruniu. Dopiero od początku lat czterdziestych katolicy zaczęli znowu przybywać do Torunia, przy ciągłym jednak wzroście liczby ewangelików. „Bezsporne jest to, że o ile do lat 60-tych XIX wieku spa-

${ }^{20}$ K. Wajda, Ludność Torunia, s. 117-119. 


\section{Wykres 1}

Ludność cywilna Torunia (wraz z członkami rodzin wojskowych) w latach 1816-1910 według wyznania (\%)

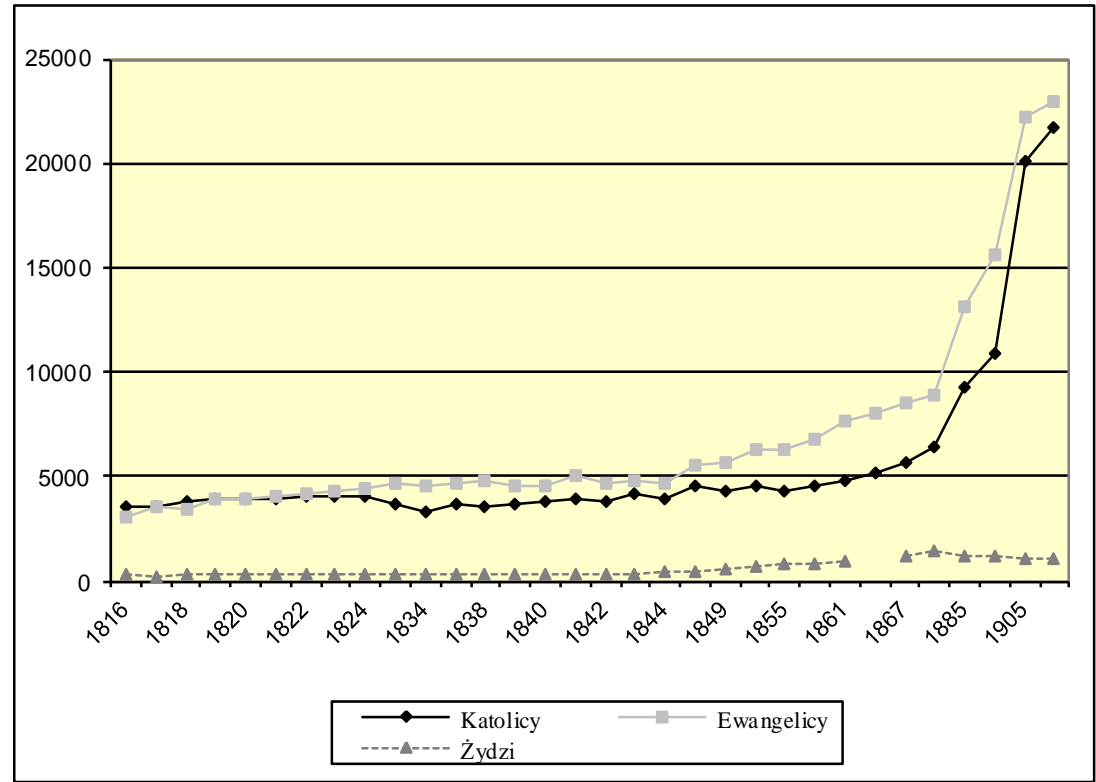

Źródło: Dane dotyczące liczby ludności według wyznania z lat 1816-1839 i 1841-1844 pochodzą z zestawień statystycznych ludności miasta Torunia i przedmieść i obejmują liczbę ludności cywilnej wraz z członkami rodzin wojskowych mieszkających poza koszarami: Archiwum Państwowe w Toruniu, Akta miasta Torunia, nr 17506; dla lat 1840, 1843, 1846-1867 pochodzą z: K. Wajda, Ludność Torunia, s. 126, tab. 8; dla lat 1871-1910 pochodzą z: tenże, Przemiany $w$ składzie wyznaniowym $i$ narodowościowym ludności Torunia $w$ XIX i początkach XX wieku, [w:] Mniejszości narodowe $i$ wyznaniowe $w$ Toruniu w XIX $i$ XX wieku, t. 3: Stosunki narodowościowe $i$ wyznaniowe na Pomorzu w XIX i XX wieku, red. M. Wojciechowski, Toruń 1993, s. 15, tab. 5; dane dla 1905 r. po włączeniu Mokrego w obręb Torunia; dane dla 1910 r. z Mokrem i po włączeniu Bielan w obręb Torunia. 
dał udział ludności polskiej [do nawet 36,8\% w $1861 \mathrm{r}$. - uwaga autorki], to od lat 80-tych wystąpiła tendencja odwrotna wyrażająca się we wzroście udziału Polaków wśród mieszkańców Torunia. Ten wzrost był wynikiem napływu robotników, głównie polskich, w związku zarówno $\mathrm{z}$ industrializacją Torunia, mimo jej ograniczonego zakresu, a zwłaszcza w związku z ożywionym ruchem budowlanym, w tym, jeśli idzie o lata 70-te do 90-tych XIX wieku, związanych z przebudową i rozbudową twierdzy toruńskiej”" ${ }^{21}$. W 1910 r. ewangelicy stanowili 50,9\%, katolicy zaś 47\% ogółu ludności. W Toruniu zamieszkiwali także Żydzi. Pierwsza połowa XIX w. była początkiem procesów emancypacyjnych Żydów w Prusach ${ }^{22}$. Liczba Żydów w Toruniu w pierwszej połowie XIX w. wynosiła około 300-400 osób. W drugiej połowie tego wieku wzrosła do 1455 osób w 1885 r., a następnie zaczęła spadać do 1005 w 1910 r. Było to głównie skutkiem emigracji Żydów na zachód Europy lub za ocean. W Toruniu spotkać też można było przedstawicieli ewangelickiej gminy reformowanej, Kościołów staroluterańskiego, grekokatolickiego i menonitów. W Toruniu istniała też grupa Czerskiego - dysydencka wobec Kościoła rzymskokatolickiego $^{23}$.

Ludność Torunia według wyznania omówiona została powyżej, dlatego w kontekście tabeli 3 należy się odnieść do pozostałych terenów powiatu. W Chełmży na przełomie XIX i XX w. dominowała ludność katolicka, stanowiąc od 57,8 do 73,9\% ogółu mieszkańców (tabela 3). Zwiększała się ona również w liczbach bezwzględnych, co było spowodowane uruchomieniem cukrowni, w której znajdowali zatrudnienie

\footnotetext{
${ }^{21}$ K. Wajda, Przemiany w sktadzie wyznaniowym, s. 24.

${ }^{22}$ Zob. Z. H. Nowak, Sprawa emancypacji Żydów w Prusach Zachodnich w pierwszej polowie XIX wieku, [w:] Emancypacja-asymilacja-antysemityzm. Żydzi na Pomorzu $w$ XIX $i$ XX wieku, t. 2: Stosunki narodowościowe $i$ wyznaniowe na Pomorzu w XIX i XX wieku, red. Z. H. Nowak, Toruń 1992, s. 7-16; tenże, Dzieje gminy żydowskiej w Toruniu (1815-1939). Zarys, [w:] Mniejszości narodowe $i$ wyznaniowe w Toruniu w XIX i XX wieku, t. 3, s. 27-37; A. Bieniaszewska, Toruński pejzaż żydowski, Toruń 2013. Szczegółowe informacje na temat ustawodawstwa dotyczącego ludności żydowskiej i statusu Żydów oraz zmian w tym zakresie na terenie zaboru pruskiego zob. A. Eisenbach, Emancypacja Żydów na ziemiach polskich 1785-1870 na tle europejskim, Warszawa 1988, s. 128-135, 212-223, 265, 553-556.

${ }^{23}$ K. Wajda, Przemiany w sktadzie wyznaniowym, s. 18.
} 
Tabela 3

Struktura wyznaniowa na terenie powiatu toruńskiego w latach 18711905

\begin{tabular}{|c|c|c|c|c|c|c|c|c|c|c|c|}
\hline \multicolumn{12}{|c|}{ Toruń } \\
\hline 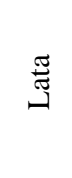 & 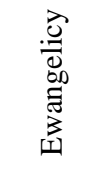 & $b^{\circ}$ & 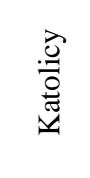 & $0^{\circ}$ & 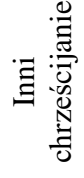 & $d^{0}$ & $\frac{\mathbb{N}}{\stackrel{N}{N}}$ & $d^{2}$ & 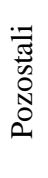 & $b^{\circ}$ & 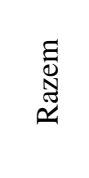 \\
\hline 1871 & 8929 & 53,7 & 6474 & 39,0 & 41 & 0,2 & 1175 & 7,1 & - & - & 16619 \\
\hline 1885 & 13101 & 54,8 & 9329 & 39,0 & 21 & 0,1 & 1455 & 6,1 & - & - & 23906 \\
\hline 1895 & 15675 & 56,2 & 10927 & 39,2 & 106 & 0,4 & 1180 & 4,2 & 1 & - & 27889 \\
\hline 1905 & 22211 & 50,9 & 20062 & 46,0 & 220 & 0,5 & 1164 & 2,7 & 1 & - & 43658 \\
\hline \multicolumn{12}{|c|}{ Chełmża } \\
\hline$\stackrel{\mathbb{\Xi}}{\Xi}$ & 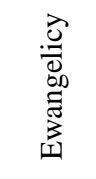 & $b^{\circ}$ & 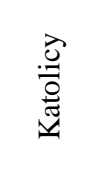 & $b^{\circ}$ & 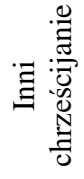 & $\delta^{\circ}$ & $\frac{\mathbb{N}}{\stackrel{N}{N}}$ & $d^{2}$ & 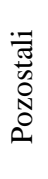 & $0^{\circ}$ & 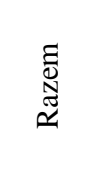 \\
\hline 1871 & 1021 & 34,2 & 1725 & 57,8 & 2 & 0,1 & 234 & 7,8 & - & - & 2982 \\
\hline 1885 & 1626 & 32,7 & 3063 & 61,7 & - & - & 279 & 5,6 & - & - & 4968 \\
\hline 1895 & 2073 & 27,4 & 5216 & 68,8 & 11 & 0,1 & 279 & 3,7 & - & - & 7579 \\
\hline 1905 & 2336 & 23,3 & 7395 & 73,9 & 11 & 0,1 & 265 & 2,6 & - & - & 10007 \\
\hline \multicolumn{12}{|c|}{ Podgórz } \\
\hline 茎 & 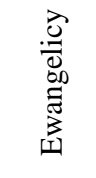 & $0^{\circ}$ & 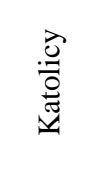 & $b^{\circ}$ & 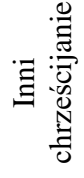 & $0^{\circ}$ & 勇 & $b^{\circ}$ & 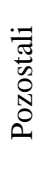 & $0^{\circ}$ & 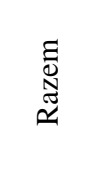 \\
\hline 1905 & 2496 & 69,0 & 1099 & 30,4 & 13 & 0,4 & 11 & 0,3 & - & - & 3619 \\
\hline
\end{tabular}




\begin{tabular}{|c|c|c|c|c|c|c|c|c|c|c|c|}
\hline \multicolumn{12}{|c|}{ Gminy wiejskie } \\
\hline 䔍 & 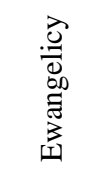 & $b^{\circ}$ & 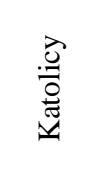 & $0^{\circ}$ & 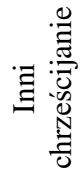 & $d^{0}$ & 胥 & de & 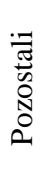 & $b^{\circ}$ & $\begin{array}{l}\text { Eี } \\
\text { స్ } \\
\text { ב. }\end{array}$ \\
\hline 1871 & 16012 & 52,9 & 13654 & 45,1 & 117 & 0,4 & 468 & 1,5 & - & - & 30251 \\
\hline 1885 & 18345 & 54,7 & 14644 & 43,7 & 253 & 0,8 & 277 & 0,8 & - & - & 33519 \\
\hline 1895 & 21794 & 53,2 & 18657 & 45,6 & 261 & 0,6 & 237 & 0,6 & 1 & - & 40950 \\
\hline 1905 & 16882 & 54,8 & 13736 & 44,6 & 141 & 0,5 & 55 & 0,2 & - & - & 30814 \\
\hline \multicolumn{12}{|c|}{ Obszary dworskie } \\
\hline 茎 & 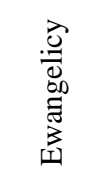 & $0^{\circ}$ & 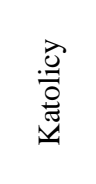 & $0^{\circ}$ & 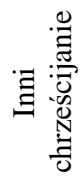 & $d^{0}$ & 胥 & $\delta^{2}$ & 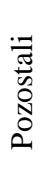 & $0^{\circ}$ & 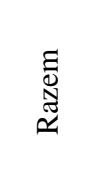 \\
\hline 1871 & 4407 & 21,4 & 16114 & 78,3 & 10 & - & 57 & 0,3 & - & - & 20588 \\
\hline 1885 & 3129 & 20,8 & 11848 & 78,9 & 16 & 0,1 & 25 & 0,2 & - & - & 15018 \\
\hline 1895 & 3836 & 23,6 & 12375 & 76,1 & 12 & 0,1 & 47 & 0,3 & 1 & - & 16271 \\
\hline 1905 & 3105 & 22,0 & 10981 & 77,9 & 4 & - & - & - & - & - & 14090 \\
\hline
\end{tabular}

Źródło: Die Gemeinden und Gutsbezirke, s. 434-443; Gemeindelexikon für die Provinz Westpreussen: auf Grund der Materialien der Volkszählung vom 1. Dezember 1885, s. 112-119; Gemeindelexikon für die Provinz Westpreussen: auf Grund der Materialien der Volkszählung vom 2. Dezember 1895, s. 108-117; Gemeindelexikon für die Provinz Westpreussen: auf Grund der Materialien der Volkszählung vom 1. Dezember 1905, s. 138-145.

robotnicy. Ewangelicy stanowili od 34,2 do 23,3\% ogółu ludności. W Chełmży zamieszkiwali także Żydzi w liczbie ponad 200 osób. Istniała też gmina żydowska ${ }^{24}$.

\footnotetext{
${ }^{24}$ Zob. A. Bieniaszewska, Żydzi w Chetmży, Toruń 2018.
} 
W 1871 r. wśród gmin wiejskich najliczniejsze było Mokre, które zamieszkiwało 2375 osób, w tym 1426 osób wyznania ewangelickiego, 926 katolików i 23 Żydów. Do licznych gmin należały także: Podgórz (1108 mieszkańców) oraz Kowalewo (1234 osoby z przewagą katolików), które jeszcze w tym roku wchodziło w skład powiatu toruńskiego, a od $1887 \mathrm{r}$. do nowo utworzonego powiatu wąbrzeskiego. Wśród obszarów dworskich dominował Ryńsk (podobnie jak Kowalewo znajdzie się w powiecie wąbrzeskim) - 1227 mieszkańców (1156 katolików). Do dużych obszarów dworskich należały też Grabie 1210 osób (771 katolików) i Turzno - 1055 osób (1029 katolików).

W 1885 r. wśród największych gmin wiejskich nadal było Mokre 6826 mieszkańców (w tym 3671 ewangelików, 3073 katolików, 75 Żydów). Podgórz liczył 1972 mieszkańców (1216 ewangelików), Wrzosy - 1234 osoby (645 ewangelików), Siemoń - 1091 (tylko 94 ewangelików), Grębocin - 1135 (większość ewangelików), Lubicz - 1167 (564 ewangelików i 576 katolików). Do najliczniejszych obszarów dworskich nadal należało Grabie - 1160 mieszkańców (739 katolików). Dużymi obszarami dworskimi były też Ostaszewo i Turzno.

W 1895 r. wśród gmin wiejskich nadal dominowało Mokre, które już wówczas liczyło 10496 mieszkańców, w tym 4883 ewangelików, 5479 katolików, 93 Żydów i 41 innych chrześcijan. Do dużych gmin wiejskich zaliczyć w tym roku należy też: Podgórz - 2945 mieszkańców z wyraźną przewagą ludności ewangelickiej (1930 osób); Rudak 1977 mieszkańców, w tym aż 1037 osób zaliczonych do ludności wojskowej i 1572 ewangelików; Grębocin - 1442 osoby z przewagą ewangelików; Wrzosy - 1390 osób z przewagą ewangelików, Lubicz - 1145 osób z przewagą katolików; Siemoń - 1131 mieszkańców z przewagą katolików. Do największych obszarów dworskich w tym roku ponownie należało Grabie liczące 1123 mieszkańców o wyraźnym charakterze katolickim.

W 1905 r. Podgórz zaliczony już został do miast z dużą przewagą ewangelików. Taka struktura wyznaniowa była wynikiem wzrostu liczby osób narodowości niemieckiej, przede wszystkim urzędników i robotników, którzy byli zatrudnieni przy budowie dworca, kolei i fortyfikacji. To zresztą także wymusiło potrzebę powołania szkoły ewangelickiej, 
którą wybudowano już w $1865 \mathrm{rr}^{25}$ Do największych gmin wiejskich ponownie zaliczony został Rudak, gdzie zamieszkiwało 2737 osób, w tym 1791 wojskowych, co z kolei przekładało się na dużą liczbę ewangelików - 2127 osób. Grębocin liczył 1683 osoby (1085 ewangelików i 578 katolików); Lubicz 1169 (652 katolików); Siemoń 1197 (1108 katolików); Wrzosy 1074 (599 ewangelików); Stawki 1006 (842 ewangelików). Do najliczniejszych obszarów dworskich nadal należało Grabie, które liczyło 1371 mieszkańców (w tym 937 katolików). Dużymi obszarami dworskimi były też Ostaszewo, Turzno, Dybowo i Gierkowo.

Tabela 4

Wyznanie/język ojczysty w powiecie toruńskim w 1905 r.

\begin{tabular}{|c|c|c|c|c|c|c|c|c|c|c|c|c|}
\hline \multirow[b]{2}{*}{ Teren } & \multicolumn{4}{|c|}{ Ewangelicy } & \multicolumn{4}{|c|}{ Katolicy } & \multirow{2}{*}{ 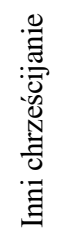 } & \multirow[b]{2}{*}{${ }_{\cdot \vec{N}}^{\vec{N}}$} & \multirow[b]{2}{*}{ 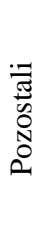 } & \multirow[b]{2}{*}{$\begin{array}{l}\frac{0}{0} \\
\frac{0}{0} \\
0 \\
0\end{array}$} \\
\hline & 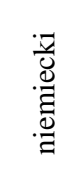 & $\frac{\vec{\sigma}}{\frac{a}{0}}$ & 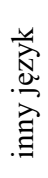 & 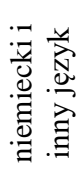 & 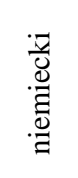 & $\begin{array}{l}\frac{\pi}{4} \\
\frac{0}{0} \\
\vdots\end{array}$ & 总 & 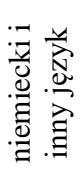 & & & & \\
\hline Chełmża & 2306 & 1 & 20 & 9 & 338 & 7022 & 3 & 32 & 11 & 265 & - & 10007 \\
\hline Podgórz & 2487 & 5 & 2 & 2 & 404 & 629 & 0 & 66 & 13 & 11 & - & 3619 \\
\hline Toruń & 22055 & 103 & 32 & 21 & 5835 & 13835 & 43 & 349 & 220 & 1164 & 1 & 43658 \\
\hline $\begin{array}{c}\text { Gminy } \\
\text { wiejskie }\end{array}$ & 16769 & 40 & 11 & 62 & 1030 & 12630 & 6 & 70 & 141 & 55 & - & 30814 \\
\hline $\begin{array}{l}\text { Obszary } \\
\text { dworskie }\end{array}$ & 3072 & 20 & 9 & 4 & 363 & 10460 & 6 & 152 & 4 & - & - & 14090 \\
\hline
\end{tabular}

Źródło: Gemeindelexikon für die Provinz Westpreussen: auf Grund der Materialien der Volkszählung vom 1. Dezember 1905, s. 138-145.

\footnotetext{
${ }^{25}$ K. Ciesielska, T. Zakrzewski, 450 lat toruńskiego Podgórza, s. 68.
} 
Dla 1905 i 1910 r. istnieją dokładniejsze dane dotyczące wyznania i języka ojczystego (tabele 4 i 5). Skorelowanie tych danych jest jednak utrudnione, gdyż układ tabel dla obu lat jest inny i w danych za 1910 rok występuje duża, nieprzyporządkowana do żadnego wyznania grupa ludności mówiącej w języku niemieckim i innym. Choć można domyślać się ich przynależności wyznaniowej (sądzić należy, iż są to W większości katolicy ${ }^{26}$ ), to jednak z punktu widzenia statystycznego pozostają grupą nieokreśloną wyznaniowo. W 1905 r. wśród ewangelików w miastach, jak i na terenach wiejskich powiatu zdecydowanie przeważały osoby deklarujące język niemiecki jako ojczysty. Ewangelicy deklarujący inny język, w tym również polski, stanowili margines. Najwięcej było ich w Toruniu - 103 osoby.

Wśród katolików proporcje dotyczące języka były już bardziej wyrównane. Większość deklarowała język polski, ale na każdym terenie była także spora grupa osób mówiących po niemiecku. W Toruniu liczyła ona aż 5835 osób. Dodatkowo wielu katolików zadeklarowało język niemiecki i inny. To cenna informacja w kontekście danych za rok 1910.

W powiecie toruńskim odnotowano także Żydów. W Toruniu było ich 1164, w Chełmży zaś 265. W Toruniu, jak i na terenie gmin wiejskich, licznie występowały też osoby zaliczane do innych chrześcijan.

W 1910 r. sytuacja kształtowała się podobnie, choć sam formularz ma inny układ (tabela 5). Ewangelicy deklarujący język polski stanowili margines, $\mathrm{i}$ to jedynie $\mathrm{w}$ Toruniu oraz na terenie gmin wiejskich i obszarów dworskich, w Chełmży zaś i na Podgórzu odnotowano ewangelików mówiących tylko po niemiecku. Z kolei wśród katolików przeważali mówiący po polsku, lecz liczba mówiących po niemiecku była również spora ${ }^{27}$. Co godne podkreślenia, praktycznie wszyscy

\footnotetext{
${ }^{26}$ Teza taka pojawia się w artykule K. Wajdy: Przemiany $w$ składzie wyznaniowym, s. 23. Wskazuje na to również L. Belzyt, Pruska statystyka językowa (18251911) a Polacy zaboru pruskiego, Mazur i Śląska, Zielona Góra 2013, s. 132-133.

${ }^{27} \mathrm{~K}$. Wajda, Polacy $i$ Niemcy $w$ Prusach Zachodnich $w$ XIX i poczatkach XX wieku, [w:] Mniejszości narodowe $i$ wyznaniowe na Pomorzu w XIX i XX wieku, t. 6 : Stosunki narodowościowe i wyznaniowe na Pomorzu w XIX i XX wieku, red. M. Wojciechowski, Torun 1998, s. 7-22.
} 
Żydzi deklarowali język niemiecki jako ojczysty (jedynie sześć osób w Toruniu oraz pięć na terenie obszarów dworskich zadeklarowało język polski). Osoby określone jako inni chrześcijanie również posługiwali się językiem niemieckim. Na uwagę zasługuje wspomniana już grupa 1142 osób odnotowana jako deklarująca język niemiecki i inny. Sądzić należy, iż w większości byli to katolicy deklarujący język niemiecki i polski, tzw. „dwujęzyczni”.

Tabela 5

Język ojczysty/wyznanie w powiecie toruńskim w $1910 \mathrm{r}$.

\begin{tabular}{|c|c|c|c|c|c|c|c|c|c|c|c|c|}
\hline \multirow[b]{2}{*}{ Teren } & \multicolumn{4}{|c|}{ Niemiecki } & \multicolumn{4}{|c|}{ Polski } & \multirow{2}{*}{ 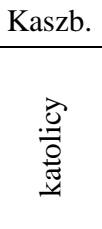 } & \multirow[b]{2}{*}{ 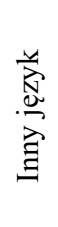 } & \multirow{2}{*}{ 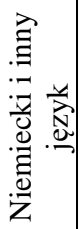 } & \multirow[b]{2}{*}{$\begin{array}{l}\frac{E}{0} \\
\frac{0}{0} \\
0\end{array}$} \\
\hline & 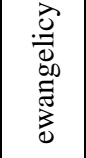 & 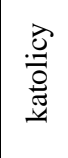 & $\begin{array}{l}\stackrel{N}{U} \\
\\
. \Xi \\
. \Xi\end{array}$ & 胥 & 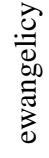 & 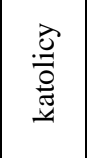 & 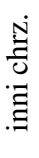 & 式 & & & & \\
\hline Toruń & 22764 & 6237 & 510 & 994 & 41 & 14842 & - & 6 & 6 & 158 & 669 & 46227 \\
\hline Chełmża & 2263 & 346 & 21 & 238 & - & 7623 & - & - & - & 49 & 72 & 10612 \\
\hline Podgórz & 2461 & 365 & 19 & 9 & - & 706 & - & - & - & - & 78 & 3638 \\
\hline $\begin{array}{c}\text { Gminy } \\
\text { wiejskie }\end{array}$ & 17427 & 910 & 247 & 45 & 24 & 13044 & - & - & - & 30 & 113 & 31840 \\
\hline $\begin{array}{l}\text { Obszary } \\
\text { dworskie }\end{array}$ & 2779 & 401 & 10 & 2 & 9 & 9507 & - & 5 & - & 52 & 210 & 12975 \\
\hline
\end{tabular}

Kaszb. - kaszubski, inni chrz. - inni chrześcijanie.

Źródło: Gemeindelexikon für die Regierungsbezirke, s. 76-83.

W XIX w. widoczna jest przez cały czas liczebna przewaga ludności katolickiej nad ewangelicką (wykres 2). Ewangelików na terenie całego powiatu toruńskiego było od 13652 w 1821 r. do 48219 w 1910 r. Rósł również odsetek tej grupy wyznaniowej z 42,9 do prawie $48 \%$ ogółu. Liczby bezwzględne katolików także rosły z 17733 w $1821 \mathrm{r}$. do 55171 w 1910 r., lecz ich odsetek spadł z 55,8\% do 50,1\% ogółu 
ludności w 1890 r., a następnie wzrósł do 52,3\% w 1910 r. Liczba Żydów na terenie powiatu, szczególnie w pierwszej połowie XIX w., była niewielka. Społeczność ta liczyła od 423 osób w 1821 r. do 1232 w 1849 r. Zwiększyła się ona w drugiej połowie tego stulecia do 1967 w 1867 r. Wartość dla 1890 r. jest już niższa i wynosi 1834 Żydów, a dla 1910 r. jeszcze mniej - 1334.

\section{Wykres 2}

Ludność powiatu toruńskiego według wyznania w XIX w. i na początku $\mathrm{XX}$ w.

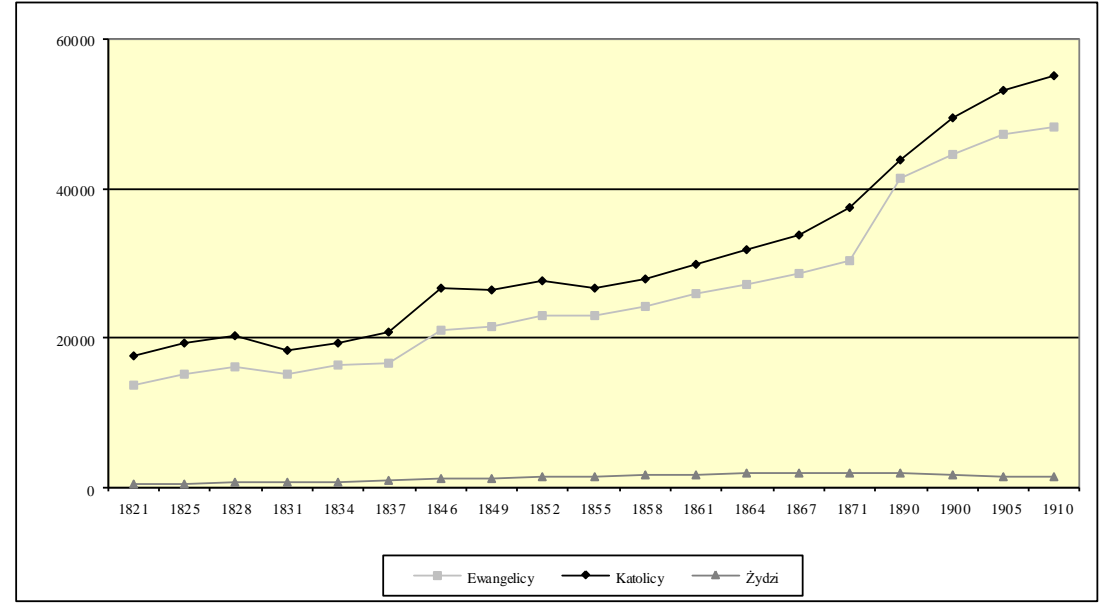

Dla 1905 i 1910 r. dane dla powiatu i miasta Toruń.

Źródło: L. Belzyt, Sprachlische Minderheiten im preussischen Staat 18151914, s. 115 .

Analiza struktury językowej powiatu toruńskiego wskazuje na dużą grupę ludności deklarującej język niemiecki jako ojczysty. Dodatkowo grupa ta powiększała się (wykres 3). W $1846 \mathrm{r}$. liczyła ona 16922 osoby, a w 1910 r. 58 256. Liczby względne utrzymywały się na poziomie od 44 do ponad 55\%. Liczba osób posługujących się językiem polskim wzrastała z 17290 w 1834 r. do 45927 w 1910 r., jednak w odsetkach udział tej grupy wynosił od 56\% do około $41 \%$ ogółu i miał wyraźną tendencję spadkową. W 1890, 1900, 1905 i 1910 r. 
odnotowano także osoby deklarujące dwa języki (niemiecki i polski) w 1900 r. było ich 2239. W 1905 i 1910 r. odnotowano też osoby deklarujące inny język. Można więc stwierdzić, iż struktura wyznaniowa i narodowościowa (określona na podstawie języka ojczystego) nakłada się na siebie tylko $\mathrm{w}$ pewnym zakresie. $Z$ danych statystycznych wynika, że część ludności katolickiej deklarowała jako ojczysty język niemiecki $^{28}$. Czyniła to także ludność żydowska.

\section{Wykres 3}

Ludność powiatu toruńskiego według języka ojczystego w XIX w. i na początku XX w.

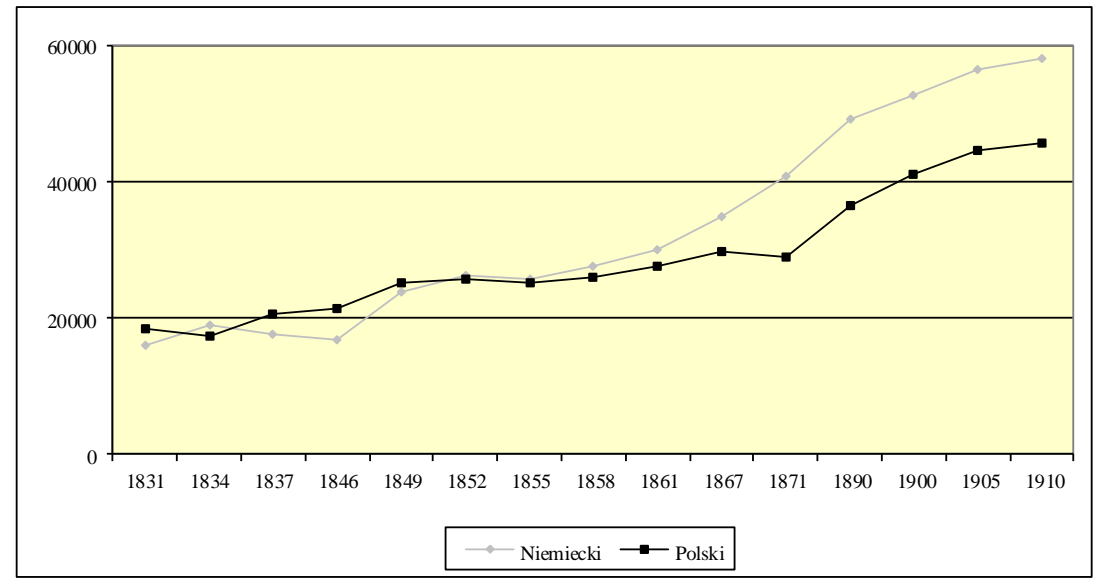

Dla 1905 i 1910 r. dane dla powiatu i miasta Torun.

Źródło: L. Belzyt, Sprachlische Minderheiten im preussischen Staat 1815 1914, s. 115.

Analizując dane językowo-narodowościowe, pochodzące ze spisów pruskich, należy jednak wziąć pod uwagę fakt, iż nie są one do końca wiarygodne. Spisy pruskie obciążone były zafałszowaniami. Wskazuje na to L. Belzyt, który dokonuje porównania tych danych z wynikami

${ }^{28}$ Więcej o germanizacji w sferze kultury i religii na terenie prowincji pruskich: E. Alabrudzińska, Stosunki religijne w Toruniu (1815-1914), [w:] Historia Torunia, t. 3, cz. 1, s. 404-406. 
spisów szkolnych w powiecie toruńskim. Na tej podstawie stwierdza, iż odsetek ludności mówiącej po polsku (również w Toruniu) był wyższy niż wykazują to statystyki urzędowe, zwłaszcza na przełomie XIX i XX w., czyli, że „od 1831 do 1910 roku proces germanizacyjny poczynił tam niewielkie postępy" 29 .

Skutkiem wielu lat zaborów było zamieszkiwanie w Toruniu, jak i na terenie powiatu na początku XX w. dużej liczby Niemców. Przemysł, rzemiosło i handel przed pierwszą wojną światową były w rękach niemieckich. Ogromne zmiany narodowościowe i wyznaniowe rozpoczęły się po powrocie Torunia i powiatu toruńskiego do Polski. Nastąpiły tu dynamiczne ruchy migracyjne, które spowodowały wymianę ludności i ważne zmiany w strukturze narodowościowej na korzyść Polaków. Niemcy opuszczali Toruń i obszar powiatu ze względów politycznoprawnych i uwarunkowań ekonomicznych. Kierowali się też niechęcią wobec polskiej suwerenności. Następowała repolonizacja tych terenów. Zmiany w strukturze narodowościowej pociągały za sobą zmiany w strukturze wyznaniowej, które widać wyraźnie zarówno w Toruniu, jak też w miastach i wsiach powiatu toruńskiego (tabela 6).

W samym Toruniu w $1921 \mathrm{r}$. katolicy stanowili 85,3\% ogółu ludności, a w 1931 r. aż 93,4\%. Odsetek ewangelików (w ogromnej większości wyznawców Kościoła Ewangelicko-Unijnego) spadł z 13,2 do $4,8 \%$. Podobnie było $\mathrm{w}$ pozostałych miastach powiatu toruńskiego (Chełmża ${ }^{30}$, Podgórz), gdzie odsetek ewangelików zmniejszył się z 9,7 do 3,1\%, a odsetek katolików wzrósł z 89,6 \% do 96,2\%. Podobnie było $\mathrm{w}$ gminach wiejskich i obszarach dworskich powiatu, gdzie odsetek ewangelików spadł z 28,8 do 15,5\%, a odsetek katolików wzrósł z 70,8 do 83,9\%. Kościół Ewangelicko-Unijny, który przez cały okres zaborów dominował i cieszył się przywilejami, tracił nie tylko wiernych, ale także swoją pozycję na rzecz Kościoła rzymskokatolickiego ${ }^{31}$.

\footnotetext{
${ }^{29}$ L. Belzyt, Pruska statystyka językowa, s. 131-134.

${ }^{30}$ L. Belzyt, Dzieje Chetmży, s. 43, tabela 5: autor przedstawia podział wyznaniowy ludności Chełmży w latach 1926-1931.

${ }^{31}$ Zob. E. Alabrudzińska, Kościoły ewangelickie na Pomorzu w okresie międzywojennym. Stosunki wewnętrzne i postawa wobec innych wyznań, [w:] Mniejszości narodowe $i$ wyznaniowe na Pomorzu w XIX $i$ XX wieku, t. 6, s. 181-200; taż, Ewangelicy
} 
Tabela 6

Struktura wyznaniowa na terenie powiatu toruńskiego w latach 1921 i 1931

\begin{tabular}{|c|c|c|c|c|c|c|c|c|c|c|c|c|}
\hline & 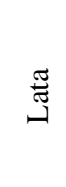 & 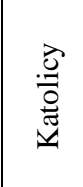 & $b^{\circ}$ & 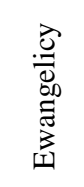 & $b^{\circ}$ & 式 & $b^{0}$ & 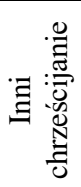 & $b^{0}$ & 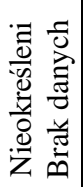 & $b^{0}$ & $\begin{array}{l}\text { Е } \\
\text { స్ } \\
\text { ֻ }\end{array}$ \\
\hline \multirow{2}{*}{ Toruń } & 1921 & 33612 & 85,3 & 5223 & 13,2 & 354 & 0,9 & 224 & 0,6 & 11 & - & 39424 \\
\hline & 1931 & 50453 & 93,4 & 2617 & 4,8 & 493 & 0,9 & 386 & 0,7 & 44 & 0,1 & 53993 \\
\hline \multirow{2}{*}{$\begin{array}{c}\text { Miasta } \\
\text { w } \\
\text { powiecie }\end{array}$} & 1921 & 12431 & 89,6 & 1340 & 9,7 & 72 & 0,5 & 36 & 0,3 & 1 & - & 13880 \\
\hline & 1931 & 15568 & 96,2 & 495 & 3,1 & 49 & 0,3 & 64 & 0,4 & 7 & - & 16183 \\
\hline \multirow{2}{*}{$\begin{array}{c}\text { Gminy } \\
\text { wiejskie } \\
\text { i } \\
\text { obszary } \\
\text { dworskie }\end{array}$} & 1921 & 28227 & 70,8 & 11486 & 28,8 & 4 & - & 169 & 0,4 & 7 & - & 39893 \\
\hline & 1931 & 36923 & 83,9 & 6831 & 15,5 & 4 & - & 247 & 0,6 & 26 & 0,1 & 44031 \\
\hline
\end{tabular}

Źródło: Skorowidz miejscowości Rzeczypospolitej Polskiej, s. 56-60; Drugi powszechny spis ludności, s. 32.

Do największych gmin wiejskich w 1921 r. należały: Grębocin, liczący 1288 osób, w tym 785 katolików; Lubicz - 1026 mieszkańców, w tym 876 katolików; Siemoń - 1083 mieszkańców, w tym aż 1051 katolików. Do największych obszarów dworskich w tym okresie zaliczyć można nadal Grabie - 555 mieszkańców, w tym 267 katolików i 287 ewangelików; Nawrę - 535 mieszkańców, sami katolicy; Ostaszewo - 604 osoby, w tym 581 katolików; Pluskowęsy - 553 osoby, tylko katolicy ${ }^{32}$.

w Toruniu $w$ latach 1920-1945, [w:] Mniejszości narodowe $i$ wyznaniowe $w$ Toruniu w XIX i XX wieku, t. 3, s. 135-157.

${ }^{32}$ Skorowidz miejscowości Rzeczypospolitej Polskiej, s. 56-60. 
W Toruniu i powiecie toruńskim w okresie międzywojennym mieszkali też Żydzi. W Toruniu było ich 354 w 1921 r. i 493 w 1931 r. Z jednej strony obszar ten opuszczali tzw. niemieccy Żydzi, lecz jednocześnie zaczęli przybywać Żydzi z byłych zaborów rosyjskiego i austriackiego. Trzeba jednak zaznaczyć, iż między Żydami napływowymi a zasiedziałymi - „tutejszymi” - dochodziło do konfliktów, ponieważ istniały duże różnice $\mathrm{w}$ ich sposobie życia, zapatrywaniach politycznych $\mathrm{i}$ formach tożsamości żydowskiej ${ }^{33}$. Żydzi zamieszkiwali też w miastach powiatu (Chełmży i Podgórzu) oraz pojedynczo na terenach wiejskich. W Chełmży odnotowywano od sześciu Żydów w 1921 r. do 72 w 1925 r. W kolejnych latach liczba tej ludności spadła i wyniosła od 20 do 44. Podobnie jak w Toruniu nastąpiła tu wymiana ludności żydowskiej ${ }^{34}$. Do innych grup wyznaniowych w Toruniu i powiecie toruńskim w okresie międzywojennym zaliczyć można też wyznawców Polskiego Narodowego Kościoła Katolickiego, prawosławnych, baptystów, metodystów, Adwentystów Dnia Siódmego, badaczy Pisma św., irwingian ${ }^{35}$.

Zmiany widoczne były także w strukturze narodowościowej (tabela 7). Według danych z $1921 \mathrm{r}$. w powiecie toruńskim dominowała ludność deklarująca narodowość polską. Odpływ ludności niemieckiej z Pomorza, który rozpoczął się jeszcze przed ostatecznymi rozstrzygnięciami w Wersalu, zdecydowanie zmienił strukturę narodowościową województwa pomorskiego na korzyść Polaków. Po 1925 r. liczba

\footnotetext{
${ }^{33}$ J. Sziling, Gminy wyznaniowe żydowskie $w$ województwie pomorskim $w$ latach 1920-1939, [w:] Mniejszości narodowe $i$ wyznaniowe $w$ województwie pomorskim w okresie międzywojennym (1920-1939), t. 1: Stosunki narodowościowe $i$ wyznaniowe na Pomorzu w XIX i XX wieku, red. M. Wojciechowski, Toruń 1991, s. 45-53; Z. H. Nowak, Gmina wyznaniowa żydowska w Toruniu w latach 1920-1939, [w:] Gminy wyznaniowe żydowskie $w$ województwie pomorskim $w$ okresie międzywojennym (19201939), t. 4: Stosunki narodowościowe $i$ wyznaniowe na Pomorzu w XIX $i$ XX wieku, red. J. Sziling, Toruń 1995, s. 59-74.

${ }^{34}$ Z. Karpus, Chetmża w okresie międzywojennym, s. 173-174.

${ }^{35}$ Z. Waszkiewicz, Stosunki wyznaniowe w Toruniu (1920-1939), [w:] Mniejszości narodowe $i$ wyznaniowe $w$ Toruniu $w$ XIX $i$ XX wieku, t. 3, s. 97-119. Zob. Metamorfozy społeczne, t. 5: Religia a społeczeństwo Drugiej Rzeczypospolitej, red. T. Stegner, Warszawa 2013.
} 
wyjeżdżających Niemców zaczęła maleć ${ }^{36}$. W Toruniu $87,1 \%$ mieszkańców deklarowało narodowość polską, w Chełmży stanowiła ona aż 91\% ogółu mieszkańców ${ }^{37}$, na Podgórzu zaś $90,1 \%$. Niemców najwięcej było w gminach wiejskich (34\%). „Exodus większości niemieckiej ludności miejskiej do Rzeszy spowodował, iż znaczącą część Niemców pomorskich stanowili mieszkańcy obszarów wiejskich"38. Na terenie obszarów dworskich Polaków było 93,1\% ogółu ludności.

\section{Tabela 7}

Ludność powiatu toruńskiego w 1921 r. według deklarowanej narodowości

\begin{tabular}{|c|c|c|c|c|c|c|c|}
\hline Obszar & Polska & $\%$ & Niemiecka & $\%$ & $\begin{array}{c}\text { Inna lub } \\
\text { niewiadoma }\end{array}$ & $\%$ & Razem \\
\hline Toruń & 34320 & 87,1 & 4923 & 12,5 & 181 & 0,5 & 39424 \\
\hline Chełmża & 9688 & 91,0 & 950 & 8,9 & 10 & 0,1 & 10648 \\
\hline Podgórz & 2912 & 90,1 & 284 & 8,8 & 36 & 1,1 & 3232 \\
\hline $\begin{array}{c}\text { Gminy } \\
\text { wiejskie }\end{array}$ & 17634 & 65,8 & 9121 & 34,0 & 57 & 0,2 & 26812 \\
\hline $\begin{array}{c}\text { Obszary } \\
\text { dworskie }\end{array}$ & 12175 & 93,1 & 892 & 6,8 & 14 & 0,1 & 13081 \\
\hline
\end{tabular}

Źródło: Skorowidz miejscowości Rzeczypospolitej Polskiej, s. 56-60.

\footnotetext{
${ }^{36}$ Zob. M. Stażewski, Rzesza w obliczu migracji po I wojnie światowej-niektóre aspekty kwestii napływu niemieckich imigrantów z ziem bytego zaboru pruskiego, [w:] Migracje polityczne i ekonomiczne w krajach nadbaltyckich w XIX i XX wieku, red. J. Borzyszkowski, M. Wojciechowski, Toruń-Gdańsk 1995, s. 93-109; M. Wojciechowski, Emigracja ludności niemieckiej z województwa pomorskiego w okresie międzywojennym (1920-1939), ibid., s. 110-124.

${ }^{37}$ L. Belzyt, Dzieje Chełmży. Autor przedstawia skład narodowościowy ludności Chełmży w latach 1926-1931: s. 41-42, tabela 4.

${ }^{38}$ P. Olstowski, Stosunki ludnościowe w województwie pomorskim, [w:] Historia Pomorza, t. 5 (1918-1939), s. 106.
} 
Tabela 8

Ludność powiatu toruńskiego w 1931 r. według języka ojczystego

\begin{tabular}{|c|c|c|c|c|c|c|c|c|c|c|c|c|c|}
\hline Obszar & $\mathrm{P}$ & $\mathrm{U}$ & $\mathrm{R}$ & $\mathrm{B}$ & $\mathrm{Ro}$ & $\mathrm{Cz}$ & $\mathrm{L}$ & $\mathrm{N}$ & $\dot{\mathrm{Z}}$ & $\mathrm{H}$ & $\mathrm{I}$ & $\mathrm{Bd}$ & Razem \\
\hline $\begin{array}{c}\text { Miasto } \\
\text { Toruń }\end{array}$ & 51006 & 35 & 8 & 3 & 113 & 10 & 1 & 2450 & 245 & 27 & 39 & 56 & 53993 \\
\hline $\begin{array}{c}\text { Miasta } \\
\text { w } \\
\text { powiecie }\end{array}$ & 15623 & 17 & - & 3 & 1 & - & - & 491 & 37 & - & - & 11 & 16180 \\
\hline $\begin{array}{c}\text { Gminy } \\
\text { i obszary } \\
\text { dworskie }\end{array}$ & 37286 & 18 & 5 & 8 & 38 & - & 9 & 6633 & 2 & - & 2 & 30 & 44023 \\
\hline $\begin{array}{c}\text { Powiat } \\
\text { razem }\end{array}$ & 103915 & 70 & 13 & 14 & 152 & 10 & 10 & 9574 & 284 & 27 & 41 & 97 & 114196 \\
\hline
\end{tabular}

$\mathrm{P}$ - polski, $\mathrm{U}$ - ukrański, $\mathrm{R}$ - ruski, B - białoruski, Ro - rosyjski, Cz - czeski, L - litewski, N - niemiecki, Ż - żydowski, H - hebrajski, I - inny, Bd - brak danych.

Źródło: Drugi powszechny spis ludności, s. 35.

Według danych z 1931 r. aż 94,4\% mieszkańców Torunia (51 006 osób) wskazało na język polski jako ojczysty, a tylko 4,5\% na język niemiecki - 2450 osób (tabela 8 ). W pozostałych miastach w powiecie stosunek ten utrzymywał się na poziomie $96,5 \%$ (15 623 osoby) do 3\% (491 osób); w gminach wiejskich i obszarach dworskich powiatu toruńskiego zaś na poziomie $84,7 \%$ (37 286 osób) do 15\% (6633 osoby). Repolonizacja, która dokonywała się we wszystkich dziedzinach życia, była więc bardzo widoczna w strukturze narodowościowej. Oprócz osób posługujących się tymi dwoma językami odnotowano między innymi osoby deklarujące języki: żydowski i hebrajski - 311 osób, rosyjski - 152, ukraiński - 70, inne -41 . Rosjanie zamieszkujący ten teren wywodzili się między innymi spośród jeńców wojennych, którzy zaczęli napływać na Pomorze Gdańskie zaraz po rozpoczęciu walk polsko-niemieckich podczas I wojny światowej. Przebywali oni $\mathrm{w}$ tworzonych dla nich obozach. Większość z nich wróciła do swojego kraju po zakończeniu wojny, jednak w sierpniu 1920 r., po zwycięstwie oddziałów polskich pod Warszawą, kolejni Rosjanie kierowani 
byli na teren Pomorza. Następni przybyli w grudniu tego roku i byli to wojskowi, członkowie tzw. „3 Armii Rosyjskiej” utworzonej na terenie Polski w celu wspólnej walki z bolszewikami. Część tych internowanych, która znalazła pracę, dostała zgodę na zamieszkanie. $\mathrm{Z}$ obozu w Toruniu około 220 osób otrzymało takie pozwolenia. Ostateczne uregulowanie problemu uchodźców z Rosji nastąpiło w 1924 r. Otrzymali oni paszporty nansenowskie i status bezpaństwowców ${ }^{39}$. Na terenie Pomorza, w tym powiatu toruńskiego, zamieszkiwali także Ukraińcy, którzy wywodzili się również z obozów dla internowanych żołnierzy i którzy w miarę zamykania obozów zaczęli się tu osiedlać i znajdować zatrudnienie. Według danych z 1937 r. w Toruniu zamieszkiwało 140, a w powiecie toruńskim 55 Ukraińców i Rusinów. Na terenie całego Pomorza było ich $1683^{40}$. Pamiętać należy, iż obcokrajowcy wchodzili także w skład Wojska Polskiego. Na Pomorzu istniały mniejszości ukraińska, białoruska i niemiecka. Każda z nich miała zresztą swoje problemy społeczno-narodowe określające stosunek do państwa polskiego, wojska i obowiązkowej służby wojskowej. Według danych z 1936 r. wśród szeregowych Wojska Polskiego było 76,4\% Polaków, 11,3\% Ukraińców, 5,9\% Żydów, 4,9\% Białorusinów, 0,9\% Niemców, a $0,5 \%$ określono jako innych. Dane dotyczące składu narodowościowego Dowództwa Okręgu Korpusu Toruń w 1936 r. wskazują na 75,7\% Polaków, 17,7\% Białorusinów, 6\% Żydów i 0,8\% Niemców ${ }^{41}$.

\footnotetext{
${ }^{39}$ Z. Karpus, Jeńcy wojenni i emigracja polityczna z Rosji na Pomorzu w latach 1914-1939 (Procesy asymilacyjne, stosunek miejscowego społeczeństwa), [w:] Migracje polityczne i ekonomiczne, s. 125-136; zob. też: tenże, Rosjanie i Ukraińcy w Toruniu w latach 1920-1939, [w:] Mniejszości narodowe i wyznaniowe w Toruniu w XIX i XX wieku, t. 3, s. 81-96.

${ }^{40}$ Z. Karpus, Rosjanie i Ukraińcy na Pomorzu w latach 1920-1939, [w:] Mniejszości narodowe i wyznaniowe na Pomorzu w XIX i XX wieku, t. 6, s. 95-114. Zob. W. Mędrzecki, Liczebność i rozmieszczenie grup narodowościowych $w$ II Rzeczypospolitej w świetle wyników II spisu powszechnego (1931 r.), Dzieje Najnowsze, 1983, nr 1-2, s. 231-252.

${ }^{41}$ W. Rezmer, Mniejszości narodowe $w$ Wojsku Polskim $w$ okresie międzywojennym, [w:] Mniejszości narodowe $i$ wyznaniowe $w$ województwie pomorskim w okresie międzywojennym (1920-1939), t. 1, s. 115-141, tab. 2, s. 122, tab. 3, s. 122; tenże, Mniejszości narodowe $i$ wyznaniowe $w$ garnizonie toruńskim $w$ latach 1920-1939, [w:] Mniejszości narodowe $i$ wyznaniowe w Toruniu w XIX i XX wieku, t. 3, s. 121-134.
} 
Wykres 4

Niemcy na terenie powiatu toruńskiego i miasta Toruń w latach 1910$1937(\%)$

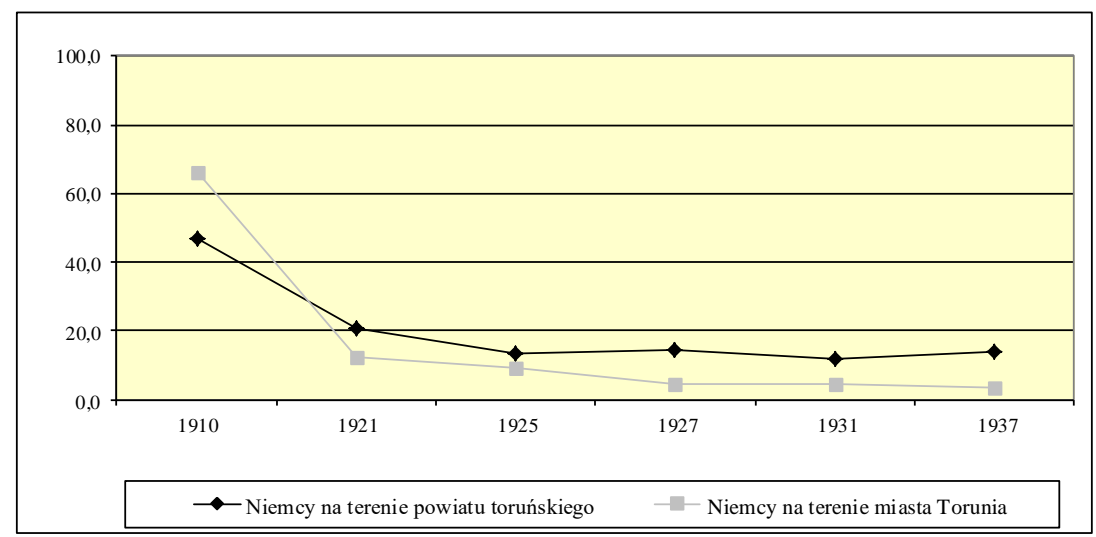

Źródło: Wykres przygotowany na podstawie danych pochodzących z: P. Olstowski, Stosunki ludnościowe w województwie pomorskim, tabela 7.

Wyraźne zmniejszenie liczby, jak i odsetka ludności niemieckiej widoczne jest również na podstawie danych statystycznych dla Torunia i powiatu toruńskiego za okres międzywojenny $\mathrm{w}$ porównaniu z 1910 r. (wykres 4). Jeszcze w 1910 r. Niemcy stanowili 66\% ogółu ludności Torunia i 46,8\% ludności powiatu, a po I wojnie światowej ich odsetek spadał w Toruniu z 12,5\% w 1921 r. do 3,5\% w 1937 r., natomiast na terenie powiatu z 20,9\% do $11,8 \%$ w $1931 \mathrm{r}$. Trzeba zaznaczyć, iż stosunki polsko-niemieckie w tym czasie w Toruniu układały się różnie. Niemcy, którzy w 1920 r. zdecydowali się tu pozostać, zachowali silną pozycję gospodarczą, ale także odrębność językową, kulturalną. Dodatkowo pomoc finansowa płynąca z Rzeszy umożliwiała im przetrwanie trudnych momentów, jak na przykład wielki kryzys gospodarczy. Według danych z 1935 r. w posiadaniu niemieckim znajdowało się w Toruniu $45 \%$ przedsiębiorstw przemysłowych zaliczanych do największych i $31 \%$ mniejszych $^{42}$.

\footnotetext{
${ }^{42}$ M. Wojciechowski, Polacy i Niemcy $w$ Toruniu $w$ latach 1920-1939, [w:] Mniejszości narodowe $i$ wyznaniowe $w$ województwie pomorskim $w$ okresie międzywo-
} 


\section{Wykres 5}

Czynni w najliczniejszych grupach zawodowych w powiecie toruńskim w $1921 \mathrm{r}$.

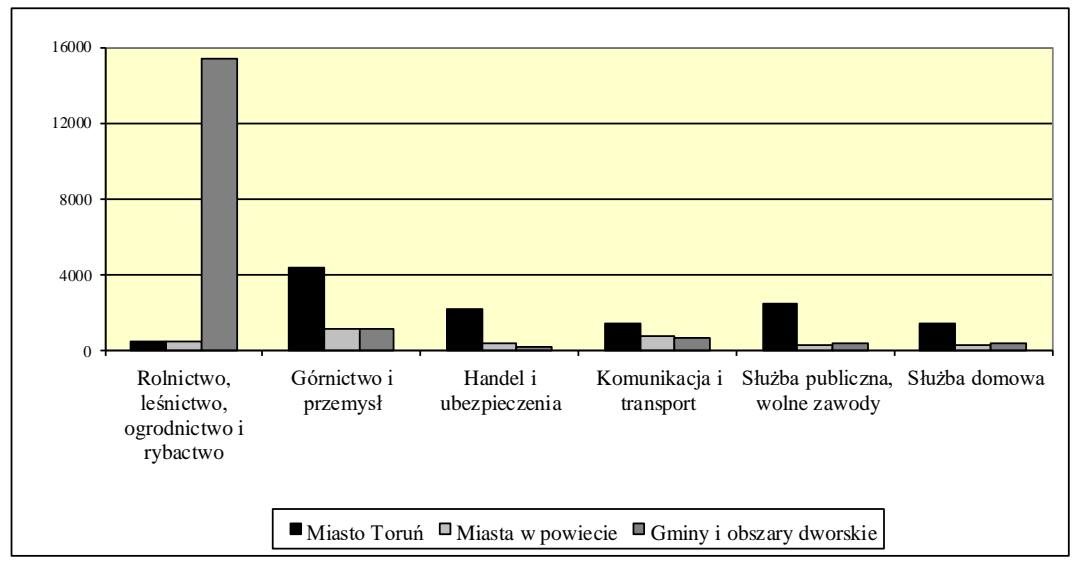

Źródło: Pierwszy powszechny spis Rzeczypospolitej Polskiej, s. 213-217.

Oba spisy międzywojenne dostarczają danych dotyczących struktury zawodowej ludności. Trzeba tu jednak zaznaczyć, iż w przypadku spisu z 1921 r. dysponujemy danymi osobno dla Torunia, miast w powiecie oraz gmin i obszarów dworskich, a w spisie z 1931 r. mamy dane odrębne jedynie dla Torunia i powiatu toruńskiego (wykresy 5,6 ). Ludność czynna, należąca do takich grup zawodowych, jak rolnictwo, leśnictwo, ogrodnictwo i rybactwo dominowała zarówno w 1921, jak i $1931 \mathrm{r}$. na terenach wiejskich w powiecie toruńskim. Z kolei ludność zatrudniona $\mathrm{w}$ przemyśle zdecydowanie przeważała w Toruniu, Chełmży i Podgórzu. Dodatkowo liczba jej wyraźnie wzrosła z 4369 do 8048 osób. Związane to było z postępującym procesem industrializacji miast, w tym z prężną działalnością największych zakładów.

Trzeba tu zaznaczyć, iż przemysł w Toruniu poniósł duże straty w czasie I wojny światowej spowodowane wywozem części maszyn

jennym (1920-1939), t. 1, s. 34-35; tenże, Mniejszość niemiecka $w$ Toruniu w latach 1920-1939, [w:] Mniejszości narodowe $i$ wyznaniowe w Toruniu w XIX i XX wieku, t. 3, s. 59-80; tenże, Mniejszości narodowe $w$ Toruniu $w$ okresie międzywojennym (1920-1939), [w:] Historia Torunia, t. 3, cz. 2, s. 195-235. 
Wykres 6

Czynni w najliczniejszych grupach zawodowych w powiecie toruńskim w $1931 \mathrm{r}$.

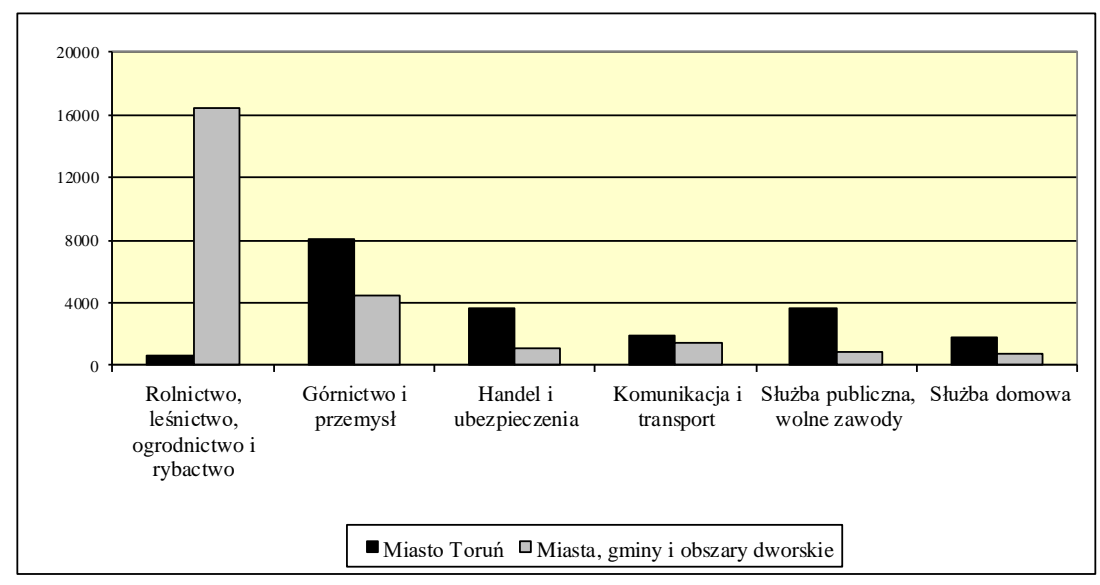

Źródło: Drugi powszechny spis ludności, s. 293-296.

i urządzeń przez fabrykantów niemieckich oraz przestawieniem produkcji wojennej na pokojową. W latach dwudziestych w Toruniu przeważały drobne fabryczki i przedsiębiorstwa. Najważniejszą gałęzią przemysłu był tu przemysł spożywczy reprezentowany przez fabryki pierników, młyny zbożowe, zakłady mięsne i ziemniaczane, fabryki tłuszczów roślinnych, rektyfikacje spirytusu i browary. Największym zakładem była założona w 1773 r. fabryka pierników Gustawa Weesego, która od 1914 r. funkcjonowała na Jakubskim Przedmieściu. Od 1910 r. działała także krochmalnia przejęta w 1921 r. przez Lubańską Fabrykę Wyrobów Ziemniaczanych „Lubań-Wronki”. Istotne miejsce zajmowała też założona w 1874 r. Toruńska Fabryka Makaronu Sichtau i S-ka. W Toruniu działał założony w 1887 r. Toruński Młyn Parowy Leopolda Rychtera (dawniej Gersona), który należał do największych na Pomorzu. W Toruniu rozwijał się także przemysł olejarski. Znajdowały się tutaj dwie z czterech pomorskich olejarni: Olejarnia i Rafineria Franciszka Woytona oraz olejarnia Längnera i Illgnera. Wymienić też trzeba wytwórnie bekonów i szynek Stanisław Jaugsch 
i S-ka, dwa browary, wytwórnie wódek i likierów oraz rektyfikacje spirytusu, np. Zakład Wacława Maćkowiaka, dawniej firma Sułtan i S-ka założona w $1858 \mathrm{r}$. W Toruniu rozwijały się także przemysły maszynowy i metalowy. Istniały założona w 1856 r. Fabryka Maszyn i Kotłów, Odlewnia Żelaza „Born i Schütze” oraz założona w 1842 r. Fabryka Maszyn Rolniczych i Odlewnia Żelaza E. Drewitza. W 1920 r. powstała natomiast Fabryka Gazomierzy i Aparatów, przemianowana później na Polską Fabrykę Wodomierzy i Gazomierzy. W mieście istniały także zakłady drukarskie, w tym działająca od 1866 r. drukarnia Józefa Buszczyńskiego. Przemysł chemiczny reprezentowany był natomiast przez utworzoną w 1922 r. Fabrykę Farb Graficznych „Atra”. W 1932 r. uruchomione zostały zakłady chemiczne „Polchem”. Największym zaś zakładem przemysłu włókienniczego była założona w 1921 r. Fabryka Obróbki Lnu „Len Pomorski” Towarzystwo Akcyjne. Mimo istnienia tych przedsiębiorstw Toruń ustępował pod każdym względem Bydgoszczy i Grudziądzowi ${ }^{43}$.

Pisząc o przemyśle w powiecie toruńskim w okresie międzywojennym wspomnieć trzeba także o Chełmży. Największym zakładem była tu nadal cukrownia, zatrudniająca w połowie lat trzydziestych nawet do 2000 pracowników. Mimo rozległych modernizacji również cukrownię dosięgnął kryzys gospodarczy. Doszło nawet do przerw w jej pracy. W mieście istniały też inne, mniejsze zakłady przemysłowe: fabryka grzebieni założona w 1922 r., fabryki maszyn rolniczych, fabryka papy i smoły braci Pichert, trzy cegielnie, fabryka octu, młyny. W mieście rozwijały się także rzemiosło, handel i usługi. Istniały hotele, restauracje i gospody. Działały rzeźnia miejska i spółdzielnia mleczarska $^{44}$.

Na terenie Podgórza w okresie międzywojennym nadal rozwijało się rzemiosło, działały też browar, młyny wodne, mleczarnia i restauracje. Wzrastała liczba domów mieszkalnych. Rozwój komunikacji miejskiej, w tym szczególnie uruchomienie w 1925 r. komunikacji

\footnotetext{
${ }^{43}$ R. Sudziński, Gospodarka Pomorza Nadwiślańskiego w Drugiej Rzeczypospolitej, [w:] Historia Pomorza, t. 5 (1918-1939), cz. 1, s. 201-207. Zob. tenże, Życie gospodarcze, [w:] Historia Torunia, t. 3, cz. 2, s. 73-110.

${ }^{44}$ Z. Karpus, Chetmża w okresie międzywojennym, s. 176-180; zob. też: L. Belzyt, Dzieje Chetmży, s. 31-32, 45-56.
} 
autobusowej z rynku na Podgórzu do rzeźni na Jakubskim Przedmieściu, miał istotny wpływ na rozwój gospodarczy i ludnościowy. Bardzo ważne było także oddanie do użytku w 1934 r. mostu drogowego przez Wisłę i poprowadzenie linii tramwajowej łączącej centrum Torunia z Dworcem Głównym ${ }^{45}$.

W 1921 r. dużo, bo aż 2450 osób było w zatrudnionych w Toruniu w służbie publicznej i wolnych zawodach. Do 1931 r. liczba ta jeszcze wzrosła do 3619 osób. Zwiększyła się też liczba osób w tej grupie zawodowej w powiecie z 518 do 850 . Kolejną grupą byli zatrudnieni w handlu i ubezpieczeniach. Liczba trudniących się szeroko pojętym handlem wzrosła z 2139 do 3617 w Toruniu, a z 523 do 1049 w powiecie. Liczna była również grupa zatrudnionych w komunikacji i transporcie (w Toruniu w 1921 r. - 1416 osób, a w 1931 r. - 1928, w powiecie odpowiednio: 1293 i 1444), a także jako służba domowa, gdzie w przypadku Torunia ich liczba wzrosła z 1365 do 1816 osób.

W okresie wielkiego kryzysu gospodarczego nastąpiło w Toruniu, podobnie jak w całym powiecie, pogorszenie sytuacji gospodarczej. Likwidacji ulegały małe i średnie przedsiębiorstwa, znacznie ograniczono produkcję w większych zakładach. W marcu 1929 r. zarejestrowano w Toruniu 1650 bezrobotnych. Nadal jednak do miasta przybywały osoby poszukujące pracy, co powodowało jeszcze większe bezrobocie. W marcu 1930 r. odnotowano już 2,5 tysiąca bezrobotnych; w grudniu 1930 r. - 3,1 tysiąca; w marcu 1932 r. - 4,3 tysiąca, w lutym 1934 r. - 3,3 tysiąca. Biorąc jednak pod uwagę, iż nie wszyscy bezrobotni byli zarejestrowani, należy sądzić, że bezrobocie w mieście było jeszcze większe ${ }^{46}$. W okresie wielkiego kryzysu stało się ono również problemem Chełmży. W połowie lat trzydziestych bez pracy pozostawało wówczas około 2000 mężczyzn, a więc wraz z rodzinami około 7000 osób z Chełmży i okolic ${ }^{47}$. „W latach 1930-1932 utworzyła się grupa osób, które bez przerwy pozostawały bez zatrudnienia. Zali-

\footnotetext{
${ }^{45}$ K. Ciesielska, T. Zakrzewski, 450 lat toruńskiego Podgórza, s. 74. Zob. R. Bugowski, Miasto w ruchu, Toruń 2018. Autor omawia uwarunkowania przestrzennoekonomiczne oraz rozwój komunikacji wewnętrznej Torunia od połowy XIX do $1939 \mathrm{r}$.

${ }^{46}$ D. Wojnarski, Powszechna historia gospodarcza, Warszawa 2004, s. 201. Skutki bezrobocia: R. Sudziński, Społeczeństwo międzywojennego Torunia, s. 59.

${ }^{47}$ Z. Karpus, Chetmża w okresie międzywojennym, s. 176-180.
} 
czyć by ich należało już nie do robotników, ale do grupy biedoty (»ubogich «) wymagających stałego wsparcia" ${ }^{48}$. Także w Podgórzu odnotowano bezrobotnych. W 1932 r. było ich 158, a zimą 1932/33 w Podgórzu i na Stawkach łącznie 568, co powodowało nawet starcia z policją ${ }^{49}$.

Toruń $\mathrm{w}$ okresie międzywojennym był jednym $\mathrm{z}$ ważniejszych ośrodków rzemieślniczych, handlowych i przemysłowych Pomorza, choć dużą konkurencję stanowiły Grudziądz, a także dynamicznie rozwijająca się Gdynia. Świetnie rozwijały się też Bydgoszcz, która dołączyła $\mathrm{z}$ województwa poznańskiego, i Włocławek - z województwa warszawskiego. Mimo wszystko można stwierdzić, iż Toruń w zakresie rozwoju gospodarczego i społecznego kontynuował tradycje przedwojenne. Nadal był stolicą powiatu, a po I wojnie światowej - województwa, nadal też stacjonował tutaj garnizon wojskowy. Te elementy odgrywały zdecydowanie rolę miastotwórczą. Z krótkiego przeglądu informacji statystyczno-demograficznych dotyczących Torunia i powiatu toruńskiego $\mathrm{w}$ okresie międzywojennym wyłania się natomiast obraz ogromnych zmian w strukturze wyznaniowej i narodowościowej ludności, zapoczątkowanych przez I wojnę światową i odzyskanie przez Polskę niepodległości.

\section{Bibliografia}

\section{Źródła}

Die Gemeinden und Gutsbezirke des Preussischen Staates und ihre Bevölkerung. 1, Die Gemeinden und Gutsbezirke der Provinz Preussen und ihre Bevölkerung: nach den Urmaterialien der allgemeinen Volkszählung vom 1. December 1871, bearb. und zusammengestellt, Königlichen statistischen Bureau, Berlin 1874.

Drugi powszechny spis ludności z dnia 9.XII.1931 roku. Mieszkania i gospodarstwa domowe. Ludność. Stosunki zawodowe. Województwo pomorskie, Warszawa 1938.

Gemeindelexikon für die Provinz Westpreussen: auf Grund der Materialien der Volkszählung vom 2. Dezember 1895 und anderer amtlicher Quellen, bearb. vom Königlichen statistischen Bureau, Berlin 1898.

\footnotetext{
${ }^{48}$ L. Belzyt, Dzieje Chetmży, s. 37.

${ }^{49}$ K. Ciesielska, T. Zakrzewski, 450 lat toruńskiego Podgórza, s. 73.
} 
Gemeindelexikon für die Provinz Westpreussen: auf Grund der Materialien der Volkszählung vom 1. Dezember 1885 und anderer amtlicher Quellen, bearb. vom Königlichen statistischen Bureau, Berlin 1887.

Gemeindelexikon für die Provinz Westpreussen: auf Grund der Materialien der Volkszählung vom 1. Dezember 1905 und anderer amtlicher Quellen, bearb. vom Königlich Preussischen Statistischen Landesamte, Berlin: Verlag des Königlichen Statistischen Landesamts, 1908.

Gemeindelexikon für die Regierungsbezirke Allenstein, Danzig, Marienwerder, Posen, Bromberg und Oppeln: auf Grund der Ergebnisse der Volkszählung vom 1. Dezember 1910 und anderer amtlicher Quellen, H. 3, Regierungsbezirk Marienwerder, bearb. von Königlich Preußischen Statistischen Landesamte, Berlin 1912.

Pierwszy powszechny spis Rzeczypospolitej Polskiej z 30.IX.1921 r. Województwo pomorskie. Mieszkania. Ludność. Stosunki zawodowe, Warszawa 1926.

Skorowidz miejscowości Rzeczypospolitej Polskiej, t. I, Województwo warszawskie, t. X, Województwo poznańskie, t. XI, Województwo pomorskie, Warszawa 1926.

\section{Opracowania}

Alabrudzińska E., Ewangelicy w Toruniu w latach 1920-1945, [w:] Mniejszości narodowe $i$ wyznaniowe $w$ Toruniu $w$ XIX $i$ XX wieku, t. 3: Stosunki narodowościowe $i$ wyznaniowe na Pomorzu $w$ XIX $i$ XX wieku, red. M. Wojciechowski, Torun 1993.

Alabrudzińska E., Kościoły ewangelickie na Pomorzu w okresie międzywojennym. Stosunki wewnętrzne i postawa wobec innych wyznań, [w:] Mniejszości narodowe $i$ wyznaniowe na Pomorzu w XIX $i$ XX wieku, t. 6: Stosunki narodowościowe $i$ wyznaniowe na Pomorzu $w$ XIX $i$ XX wieku, red. M. Wojciechowski, Toruń 1998.

Alabrudzińska E., Stosunki religijne w Toruniu (1815-1914), [w:] Historia Torunia, red. M. Biskup, t. 3, cz. 1: W czasach zaboru pruskiego (17931920), Toruń 2003.

Bartko M., Lau W., 100 lat cukrowni Chetmża 1882-1982, Chełmża 1982.

Belzyt L., Dzieje Chetmży w okresie międzywojennym (1920-1939), Toruń 2001.

Belzyt L., Pruska statystyka językowa (1825-1911) a Polacy zaboru pruskiego, Mazur i Ślaska, Zielona Góra 2013.

Belzyt L., Sprachlische Minderheiten im preussischen Staat 1815-1914. Die preussische Sprachenstatistik in Bearbeitung und Kommentar, Marburg 1998. 
Bieniaszewska A., Toruński pejzaż żydowski, Toruń 2013.

Bieniaszewska A., Żydzi w Chetmży, Toruń 2018.

Biskup K., Narębski L., Prusko-niemiecka twierdza Toruń (1815-1914), [w:] Historia Torunia, red. M. Biskup, t. 3, cz. 1: W czasach zaboru pruskiego (1793-1920), Toruń 2003.

Bugowski R., Miasto w ruchu, Torun 2018.

Ciesielska K., Zakrzewski T., 450 lat toruńskiego Podgórza 1555-2005, Toruń 2005.

Ciesielska K., Ustrój i organizacja władz i kancelarii miasta Torunia w latach 1793-1919, Warszawa 1972.

Eisenbach A., Emancypacja Żydów na ziemiach polskich 1785-1870 na tle europejskim, Warszawa 1988.

Karpus Z., Chetmi̇a w okresie międzywojennym, [w:] Dzieje Chetmży, red. M. Wojciechowski, Chełmża 1994.

Karpus Z., Jeńcy wojenni i emigracja polityczna z Rosji na Pomorzu w latach 1914-1939 (Procesy asymilacyjne, stosunek miejscowego spoleczeństwa), [w:] Migracje polityczne i ekonomiczne $w$ krajach nadbaltyckich $w$ XIX i XX wieku, red. J. Borzyszkowski, M. Wojciechowski, Toruń-Gdańsk 1995.

Karpus Z., Rosjanie i Ukraińcy na Pomorzu w latach 1920-1939, [w:] Mniejszości narodowe $i$ wyznaniowe na Pomorzu w XIX i XX wieku, t. 6: Stosunki narodowościowe $i$ wyznaniowe na Pomorzu $w$ XIX $i$ XX wieku, red. M. Wojciechowski, Toruń 1998.

Karpus Z., Rosjanie i Ukraincy w Toruniu w latach 1920-1939, [w:] Mniejszości narodowe $i$ wyznaniowe $w$ Toruniu, t. 3: Stosunki narodowościowe i wyznaniowe na Pomorzu w XIX i XX wieku, red. M. Wojciechowski, Toruń 1993.

Mędrzecki W., Liczebność i rozmieszczenie grup narodowościowych w II Rzeczypospolitej w świetle wyników II spisu powszechnego (1931 r.), Dzieje Najnowsze, 1983, nr 1-2, s. 231-252.

Metamorfozy społeczne, t. 5: Religia a społeczeństwo Drugiej Rzeczypospolitej, red. T. Stegner, Warszawa 2013.

Mikulski K., Poczatki zaboru pruskiego (1793-1806), [w:] Historia Torunia, red. M. Biskup, t. 3, cz. 1: W czasach zaboru pruskiego (1793-1920), Toruń 2003.

Nowak Z. H., Z dziejów toruńskich Żydów w czasach międzywojennych, [w:] Mniejszości narodowe $i$ wyznaniowe $w$ województwie pomorskim $w$ okresie międzywojennym (1920-1939), t. 1: Stosunki narodowościowe $i$ wyznaniowe na Pomorzu w XIX $i$ XX wieku, red. M. Wojciechowski, Toruń 1991. 
Nowak Z. H., Dzieje gminy żydowskiej w Toruniu (1815-1939). Zarys, [w:] Mniejszości narodowe $i$ wyznaniowe $w$ Toruniu $w X I X$ i XX wieku, t. 3: Stosunki narodowościowe $i$ wyznaniowe na Pomorzu $w$ XIX i XX wieku, red. M. Wojciechowski, Toruń 1993.

Nowak Z. H., Gmina wyznaniowa żydowska w Toruniu w latach 1920-1939, [w:] Gminy wyznaniowe żydowskie $w$ województwie pomorskim $w$ okresie międzywojennym (1920-1939), t. 4: Stosunki narodowościowe $i$ wyznaniowe na Pomorzu w XIX i XX wieku, red. J. Sziling, Torun 1995.

Nowak Z. H., Sprawa emancypacji Żydów w Prusach Zachodnich, [w:] Emancypacja-asymilacja-antysemityzm. Żydzi na Pomorzu w XIX $i$ XX wieku, t. 2: Stosunki narodowościowe $i$ wyznaniowe na Pomorzu $w$ XIX i XX wieku, red. Z. H. Nowak, Toruń 1992.

Olstowski P., Stosunki ludnościowe w województwie pomorskim, [w:] Historia Pomorza, t. 5 (1918-1939). Województwo pomorskie $i$ Wolne Miasto Gdańsk, cz. 1: Ustrój, społeczeństwo i gospodarka, red. Sz. Wierzchosławski, P. Olstowski, Toruń 2015.

Rezmer W., Mniejszości narodowe $i$ wyznaniowe $w$ garnizonie toruńskim $w$ latach 1920-1939, [w:] Mniejszości narodowe $i$ wyznaniowe $w$ Toruniu w XIX i XX wieku, t. 3: Stosunki narodowościowe i wyznaniowe na Pomorzu w XIX i XX wieku, red. M. Wojciechowski, Torun 1993.

Rezmer W., Mniejszości narodowe $w$ Wojsku Polskim $w$ okresie międzywojennym, [w:] Mniejszości narodowe $i$ wyznaniowe $w$ województwie pomorskim $w$ okresie międzywojennym (1920-1939), t. 1: Stosunki narodowościowe $i$ wyznaniowe na Pomorzu w XIX $i$ XX wieku, red. M. Wojciechowski, Toruń 1991.

Salm J., Przemiany przestrzenne pruskiego Torunia (1815-1914), [w:] Historia Torunia, red. M. Biskup, t. 3, cz. 1: W czasach zaboru pruskiego (1793-1920), Toruń 2003.

Salmonowicz S., Administracja $i$ prawo $w$ prowincjach pomorskich, [w:] Historia Pomorza, t. 4 (1850-1918), cz. 1: Ustrój, gospodarka, społeczeństwo, red. S. Salmonowicz, Toruń 2000.

Salmonowicz S., Podzialy terytorialne i organizacja administracji $w$ województwie pomorskim (1920-1939), [w:] Historia Pomorza, t. 5 (19181939). Województwo pomorskie i Wolne Miasto Gdańsk, cz. 1: Ustrój, społeczeństwo i gospodarka, red. Sz. Wierzchosławski, P. Olstowski, Toruń 2015.

Salmonowicz S., Podziaty terytorialne i ustrój polityczny ziem pomorskich w latach 1815-1850, [w:] Historia Pomorza, t. 3 (1815-1850), cz. 1: Gospodarka, społeczeństwo, ustrój, red. G. Labuda, Poznań 1993. 
Stażewski M., Rzesza w obliczu migracji po I wojnie światowej - niektóre aspekty kwestii naplywu niemieckich imigrantów z ziem byłego zaboru pruskiego, [w:] Migracje polityczne i ekonomiczne $w$ krajach nadbaltyckich w XIX i XX wieku, red. J. Borzyszkowski, M. Wojciechowski, ToruńGdańsk 1995.

Sudziński R., Społeczeństwo międzywojennego Torunia, [w:] Historia Torunia, red. M. Biskup, t. 3, cz. 2: W czasach Polski Odrodzonej i okupacji niemieckiej (1920-1945), Torun 2006.

Sudziński R., Gospodarka Pomorza Nadwiślańskiego w Drugiej Rzeczypospolitej, [w:] Historia Pomorza, t. 5 (1918-1939), cz. 1: Ustrój, społeczeństwo i gospodarka, red. Sz. Wierzchosławski, P. Olstowski, Toruń 2015.

Sudziński R., Życie gospodarcze, [w:] Historia Torunia. red. M. Biskup, t. 3 , cz. 2: W czasach Polski Odrodzonej i okupacji niemieckiej (1920-1945), Toruń 2006.

Sziling J., Gminy wyznaniowe żydowskie $w$ województwie pomorskim w latach 1920-1939, [w:] Mniejszości narodowe $i$ wyznaniowe $w$ województwie pomorskim $w$ okresie międzywojennym (1920-1939), t. 1: Stosunki narodowościowe $i$ wyznaniowe na Pomorzu w XIX i XX wieku, red. M. Wojciechowski, Torun 1991.

Wachowiak B., Sytuacja gospodarcza Prus Zachodnich $w$ świetle sprawozdania Prowincjonalnej Dyrekcji Podatkowej w Gdańsku za 1840 rok, Acta Universitatis Nicolai Copernici, Historia XXX - Nauki HumanistycznoSpołeczne, z. 322, Toruń 1997, s. 125-134.

Wajda K., Chetmża pod zaborem pruskim (do 1914 r.), [w:] Dzieje Chetmży, red. M. Wojciechowski, Chełmża 1994.

Wajda K., Ludność Torunia (1815-1914), [w:] Historia Torunia, red. M. Biskup, t. 3, cz. 1: W czasach zaboru pruskiego (1793-1920), Toruń 2003.

Wajda K., Pod ponownym pruskim panowaniem (1815-1920), [w:] Toruń dawny i dzisiejszy, red. M. Biskup, Warszawa 1983.

Wajda K., Polacy $i$ Niemcy $w$ Prusach Zachodnich $w$ XIX i poczatkach XX wieku, [w:] Mniejszości narodowe $i$ wyznaniowe na Pomorzu w XIX i XX wieku, t. 6: Stosunki narodowościowe $i$ wyznaniowe na Pomorzu $w$ XIX i XX wieku, red. M. Wojciechowski, Torun 1998.

Wajda K., Przemiany w składzie wyznaniowym i narodowościowym ludności Torunia $w$ XIX i poczatkach XX wieku, [w:] Mniejszości narodowe $i$ wyznaniowe $w$ Toruniu $w$ XIX $i X X$ wieku, t. 3: Stosunki narodowościowe $i$ wyznaniowe na Pomorzu w XIX i XX wieku, red. M. Wojciechowski, Toruń 1993. 
Wajda K., Życie gospodarcze miasta (1815-1914), [w:] Historia Torunia, red. M. Biskup, t. 3, cz. 1: W czasach zaboru pruskiego (1793-1920), Toruń 2003.

Waszkiewicz Z., Stosunki wyznaniowe w Toruniu (1920-1939), [w:] Mniejszości narodowe $i$ wyznaniowe w Toruniu $w$ XIX i XX wieku, t. 3: Stosunki narodowościowe $i$ wyznaniowe na Pomorzu $w$ XIX $i$ XX wieku, red. M. Wojciechowski, Toruń 1993.

Wojciechowski M., Mniejszości narodowe w Toruniu $w$ okresie międzywojennym (1920-1939), [w:] Historia Torunia, red. M. Biskup, t. 3, cz. 2: W czasach Polski Odrodzonej i okupacji niemieckiej (1920-1945), Toruń 2006.

Wojciechowski M., Antysemityzm na Pomorzu w okresie międzywojennym, [w:] Emancypacja-asymilacja-antysemityzm. Żydzi na Pomorzu w XIX $i X X$ wieku, t. 2: Stosunki narodowościowe $i$ wyznaniowe na Pomorzu w XIX i XX wieku, red. Z. H. Nowak, Torun 1992.

Wojciechowski M., Emigracja ludności niemieckiej z województwa pomorskiego w okresie międzywojennym (1920-1939), [w:] Migracje polityczne $i$ ekonomiczne $w$ krajach nadbattyckich $w$ XIX $i$ XX wieku, red. J. Borzyszkowski, M. Wojciechowski, Toruń-Gdańsk 1995.

Wojciechowski M., Mniejszość niemiecka w Toruniu w latach 1920-1939, [w:] Mniejszości narodowe $i$ wyznaniowe w Toruniu w XIX i XX wieku, t. 3: Stosunki narodowościowe i wyznaniowe na Pomorzu w XIX i XX wie$k u$, red. M. Wojciechowski, Torun 1993.

Wojciechowski M., Polacy i Niemcy w Toruniu w latach 1920-1939, [w:] Mniejszości narodowe $i$ wyznaniowe $w$ województwie pomorskim $w$ okresie międzywojennym (1920-1939), t. 1: Stosunki narodowościowe i wyznaniowe na Pomorzu w XIX i XX wieku, red. M. Wojciechowski, Torun 1991.

Wojnarski D., Powszechna historia gospodarcza, Warszawa 2004.

Zielińska A., Przemiany struktur demograficznych $w$ Toruniu $w$ XIX i na początku XX wieku, Torun 2012.

Zielińska-Nowicka A., W poszukiwaniu lepszego jutra. Procesy migracyjne mieszkańców Torunia w I połowie XIX wieku, Toruń 2006. 